International Journal of Physical Research, $10(1)(2022) 18-32$
International Journal of Physical Research
SPC
Website: www.sciencepubco.com/index.php/IJPR
Research paper

\title{
Determination of yearly performance and degradation rate of electrical parameters of amorphous silicon photovoltaic module in Minna, Nigeria
}

\author{
Matthew, Samuel Oluwatobi ${ }^{1 *}$, Ezenwora, Joel Aghaegbunam², Eichie Julia \\ Ofure $^{3}$, AliluSaliuOlakanmi ${ }^{4}, \mathrm{Ahmadu}, \mathrm{Aliyu}^{5}$ \\ ${ }^{1}$ Department of Physics, Federal University of Technology, P.M.B. 65, Minna, Nigeria \\ *Corresponding author E-mail:sammyline4all@gmail.com
}

\begin{abstract}
There is need for accurate knowledge of degradation rate and lifespan of photovoltaic (PV) module in every location for an effective solar PV power system. Outdoor degradation analysis was carried out on amorphous silicon PV module rated $10 \mathrm{~W}$ using CR1000 software-based Data Acquisition System (DAS). The PV module under test and meteorological Sensors were installed on a metal support structure at the same test plane. The data monitoring was from 09:00 to 18:00 hours each day continuously for a period of four years, from December 2014 to November 2018. Annual yearly averages of the performance variables were carried out to ascertain the degradation rate and lifespan of the module. The module performance for the four years of study was compared with Standard Test Condition (STC) specifications. The maximum power achieved at $1000 \mathrm{~W} / \mathrm{m} 2$ for the four years of study were $0.652 \mathrm{~W}, 2.186 \mathrm{~W}, 2.078 \mathrm{~W}$, and $1.812 \mathrm{~W}$ representing $6.52 \%, 21.86 \%, 20.78 \%$ and $18.12 \%$ of the manufacturer's $10 \mathrm{~W}$ specification. Module efficiency at $1000 \mathrm{~W} / \mathrm{m} 2$ for the four years of study is $2.25 \%, 7.56 \%, 7.19 \%$, and $6.27 \%$ respectively as against the manufacturers STC specification of $33 \%$. Accordingly, Module Performance Ratios for the PV module investigated were 0.07, 0.23, 0.22 and 0.19 respectively. For the Rate of Degradation (RoD), it was observed that Open-Circuit voltage (Voc), Short-Circuit Current (Isc), Power-Output (P), Maximum Power (Pmax), had an average yearly degradation rate of $0.73 \mathrm{~V}, 0.010 \mathrm{~A}, 0.040 \mathrm{~W}, 0.050 \mathrm{~W}$ respectively for the four years of study. To also determine the lifespan of the module, an empirically determined statistical model given as YEAR $=3.36-0.237$ Voc (v) -71.5 Isc (A) + 8.07 Power (W) was fitted to the observed data to predict the lifetime of the module at any given year.
\end{abstract}

Keywords:Amorphous; Module; Photovoltaic.

\section{Introduction}

There is need for accurate knowledge of degradation rate and lifespan of photovoltaic (PV) module in every location for an effective solar PV power system. PV cells/modules due to their exposure to atmospheric parameters such as solar irradiance, temperature, wind speed, Relative humidity which depreciates the electrical parameters of these modules. The limited lifetime is as a result of several factors that are in play simultaneously. The performance of PV modules has been observed to gradually decrease with operation time [1]. Long term performance of PV modules is vital if they have to pay back to the consumer. It is important to investigate the performance parameters of the modules. With rapid economic growth and improvement in living standards, there has been a marked increase in energy consumption in many third world countries. Most countries use fossil fuel, hydroelectric power and nuclear power as a source of energy. Nuclear and fossil fuels have adverse effects on the environment such as large amounts of greenhouse gases emissions and pollution from the burning of fossil fuel [2][3].

Since fossil fuel and nuclear sources of energy are not renewable, it is necessary to explore other sources of energy that are cost effective especially in the developing countries that rely heavily on imported fossil fuel. Renewable energy such as sunlight, wind tides and wave can be particularly suitable for developing countries especially in rural and remote areas where transmission and distribution of energy generated from fossil fuels can be difficult and expensive. Producing renewable energy locally can offer a viable alternative.

Technology advances are opening up a huge new market for solar power. Even though they are typically poor, these people have to pay far more for lighting than people in rich countries because they use inefficient energy systems like kerosene lamps and stoves. Solar power costs half as much as lighting with kerosene. According to [4].An estimated three million households get power from small solar panels.

The energy conversion efficiency of a PV module or array as a group of electrically connected PV modules in the same plane is defined as the ratio between electrical power conducted away from the module and the incidence power of the sun [5].

This conversion efficiency of photovoltaic (PV) modules by manufacturers is done under Standard Test Conditions (STC). The Standard Test Conditions are module temperature of $25^{\circ} \mathrm{C}$, Irradiance of $1000 \mathrm{~W} / \mathrm{M}^{2}$ and Air mass of 1.5). Different PV module technologies now 
exist in the market. These include crystalline modules such as mono/single crystalline, poly/multi crystalline and amorphous modules. The modules available are rated by manufacturer depending on their power output such as $5 \mathrm{Watts}, 10 \mathrm{Watts}, 15 \mathrm{Watts}$. The choice of the module to use depends on the power output needed by the consumer and its efficiency. Photovoltaic (PV) modules are often considered as the most reliable elements in PV systems. However, PV module reliability data are not shown on commercial data sheets in the same way as it is with other products such as electronic devices and electric power supplies. Conversely, the high reliabilities associated with PV modules are indirectly reflected in the output power warranties usually provided in the industry, which range from $25-30$ years. As a matter of fact, PV modules have a low return time, the exceptions being the catastrophic failures. The performance of PV modules decreases when deployed outdoors over time. After several years of operation, this decrease will affect PV module reliability [6]. Therefore, this study was carried out with the-state-of-the-art Data Acquisition System (DAS) to determine the yearly degradation rate of electrical parameters of amorphous silicon PV module and the findings can be used to plan/design an effective and reliable PV Power system in any location.

\section{Materials and method}

\subsection{Method of data acquisition}

The degradation rate of the amorphous silicon PV module was monitored in Minna environment, using CR1000 software-based data logging system with computer interface. The PV modules under test, and meteorological sensors, were installed on support structure at the same test plane, at about three meters of height, so as to ensure adequate exposure to insolation and enough wind speed, since wind speed is proportional to height. The elevation equally ensures that the system is free from any shading from shrubs and also protected from damage or interference by intruders. Also, the whole experimental set up is secured in an area of about four meters in diameter. The modules are tilted at approximately $10^{\circ}$ (since Minna is on latitude $09^{\circ} 37^{\prime} \mathrm{N}$ ) to horizontal and south-facing to ensure maximum insolation [7 - 9]. The data monitoring was from $9.00 \mathrm{am}$ to $6.00 \mathrm{pm}$ local time, each day continuously for a period of four years, spanning from December 2014 to November 2018. The experiment was carried out near physics department, Federal University of Technology, Minna (latitude $09037^{\prime} \mathrm{N}$, longitude $06^{\circ} 32^{\prime} \mathrm{E}$ and 249 meters above sea level). The sensors are connected directly to the CR1000 Campbell Scientific data logger, while the module is connected to the logger via electronic loads. The logger was programmed to scan the load current from 0 to $1 \mathrm{~A}$ at intervals of 50mA every 5 minutes, and average values of short-circuit current, Isc, open-circuit voltage, Voc, current at maximum power, Imax, voltage at maximum power, Vmax, power and maximum power obtained from the modules together with the ambient parameters are recorded and logged. Data download at the data acquisition site was performed every 7 days to ensure effective and close monitoring of the data acquisition system (DAS). At the end of each month and where necessary, hourly, daily and monthly averages of each of the parameters-solar irradiance, solar insolation, wind speed, ambient and module temperatures, and the output response variables (open-circuit voltage, Voc, short-circuit current, Isc, voltage at maximum power, Vmax, current at maximum power, Imax, efficiency, Eff, and fill factor, FF) of the photovoltaic modules were obtained. The global solar radiation was monitored using Li200SA M200 Pyranometer, manufactured by LI-COR Inc.USA, with calibration of 94.62 microamperes per $1000 \mathrm{~W} / \mathrm{m}^{2}$. The ambient temperature and relative humidity was monitored using HC2S3-L Rotronic HygraClip2 temperature/relative humidity probe, manufactured in Switzerland. Wind speed was monitored using 03002-L RM Young Wind Sentry Set. And module temperature was monitored using 110PV-L Surface-Mount Temperature probe. All sensors are installed in the CR1000 Campbell Scientific data logger with measurement and control module.

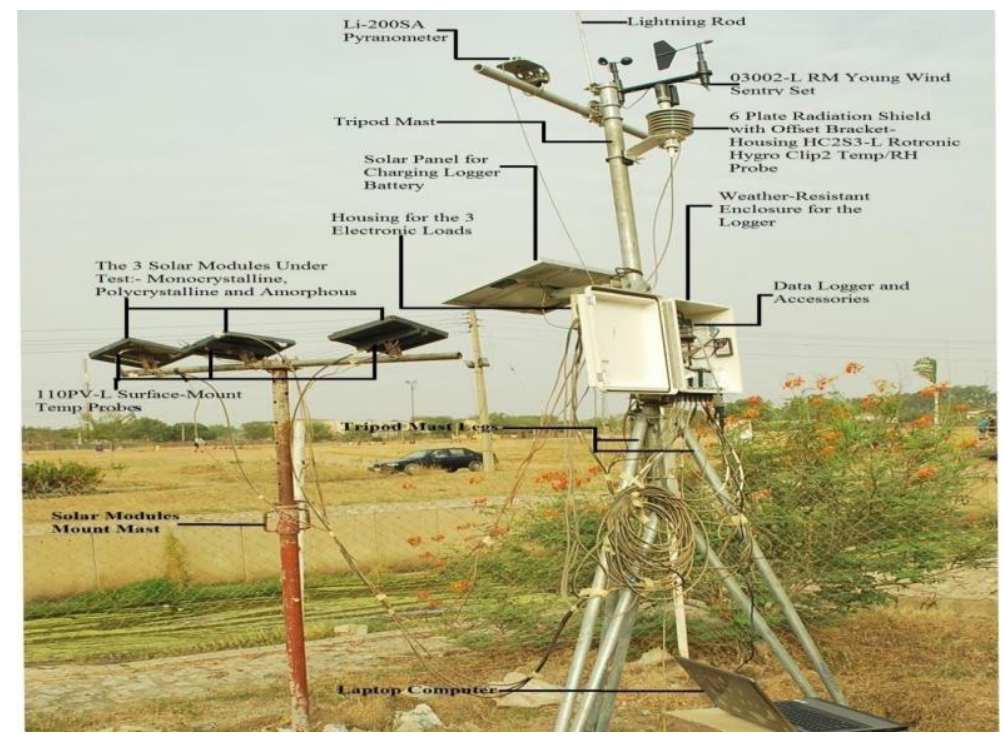

The Experimental Set Up (Near Physics Department, FUT Minna).

\subsection{Method of data analysis}

Degradation rate of the amorphous module was investigated in terms of open-circuit voltage, Voc, short-circuit current, Isc, voltage at maximum power, Vmax, current at maximum power, Imax, efficiency, Eff, and fill factor, FF. Fill factor, FF, and Efficiency, Eff, were evaluated using the following expressions [8][9]:

Fill factor, FF = Imax Vmax/IscVoc 
Efficiency, Eff = ImaxVmax /Pin = IscVoc FF/Pin = IscVoc FF/AEe

$\mathrm{MPR}=$ Effective Efficiency / Efficiency at STC

Where $P_{\text {in }}=$ power input

$\mathrm{A}=$ Area of the Amorphous Module

$\mathrm{Ee}=$ Solar Irradiance

In order to determine the Rate of Degradation (ROD), a statistical analysis was performed on the observed data with the aid of statistical package; Minitab 17 and Microsoft excel used for prediction of performance variables are presented. Multiple regression models, analysis of variance (ANOVA) and twenty years forecast using the model developed was done with the aim of establishing the statistical significant relationship between the variables thereby predicting the lifetime of the amorphous module. The regression equation is

$\mathrm{Y}=\mathrm{a}-\mathrm{b} \mathrm{V}_{\mathrm{oc}}-\mathrm{cI} \mathrm{sc}+\mathrm{dPower}$

The I-V curves were produced by plotting current against voltage produced by the logger in scanning the electronic load current from 0 to $1 \mathrm{~A}$ at intervals of $50 \mathrm{~mA}$. The maximum power point, $\mathrm{P}_{\max }$, which is the operating point of the module, was equally recorded by the logger. This maximum power point also corresponds to the largest area of the rectangle that fits the curve. The current and voltage at this point are $\mathrm{I}_{\max }$ and $\mathrm{V}_{\max }$ respectively.

\section{Results and discussions}

The output characterization of solar modules (monocrystalline, polycrystalline and amorphous) is usually based on trends of the I-V curve as a function of global irradiance. The amorphous module under study using four years data does not depict diode characteristics that are usually associated with solar modules. The reason is because the manufacturer's specifications are particularly too unrealistic that its actual performance is far below the range of electronic load designed for it, which was based on the specification of the manufacturer. It was discovered that the manufacturer's specification current was 0.62 amperes, but no year was able to deliver up to 0.1 amperes of current for the four years of study and this explains the sudden descent in the characteristic curve immediately it was loaded giving slanting lines instead of a curve that is normal to other types of modules (monocrystalline and polycrystalline) as seen in Figures 1 to 4 .

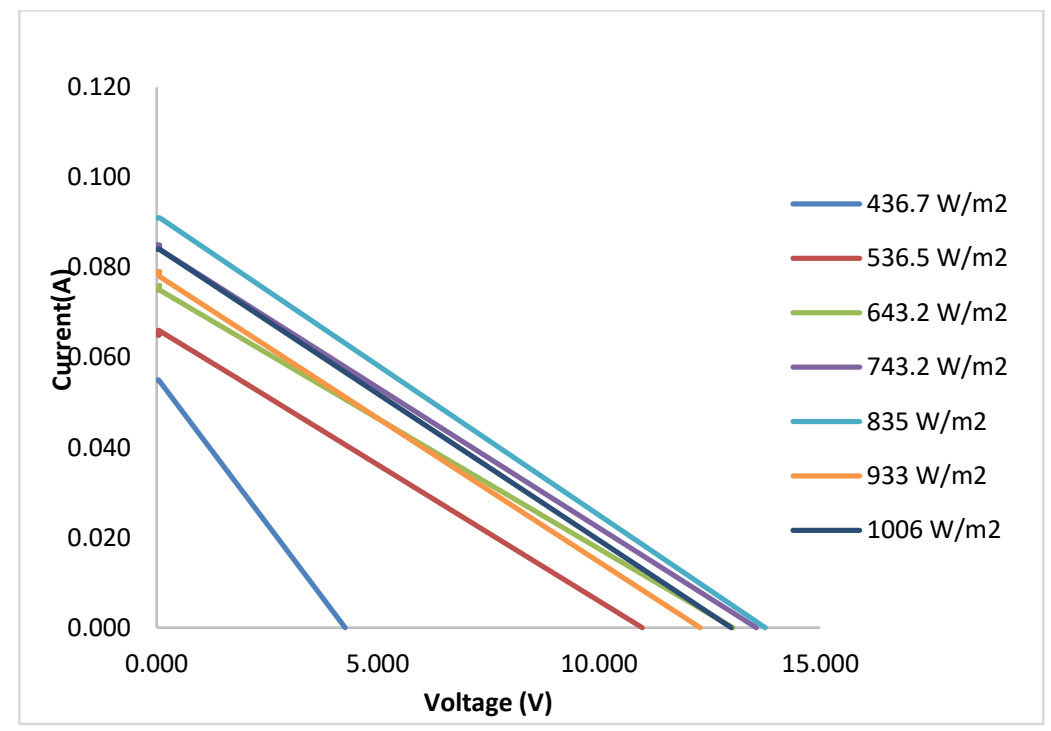

Fig. 1:I-V Characteristics of the Amorphous Silicon Module as A Function of Global Irradiance for the First Year.

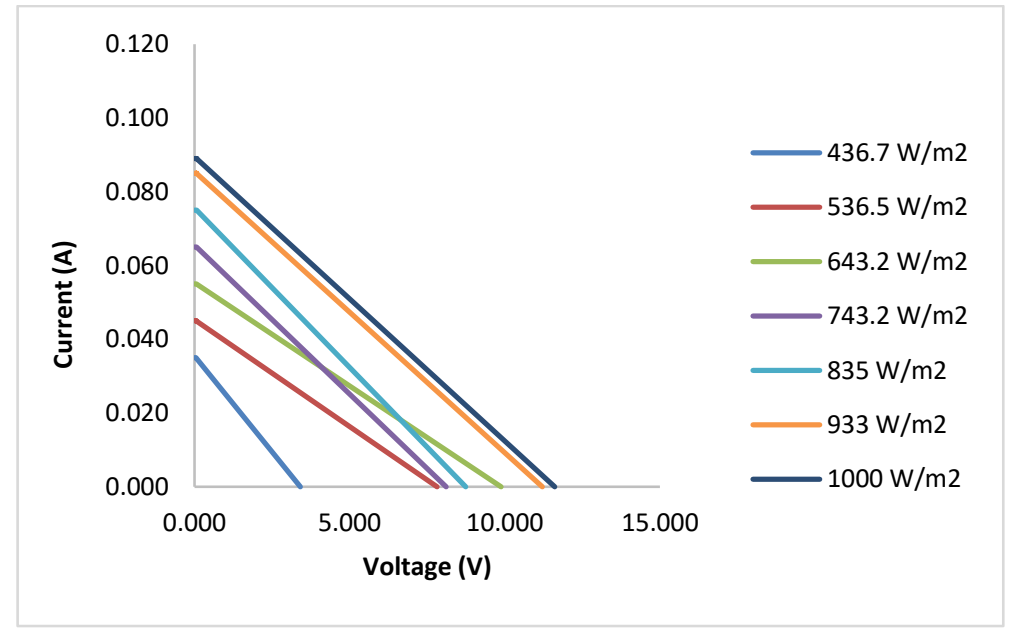

Fig. 2:I-V Characteristics of the Amorphous Silicon Module as A Function of Global Irradiance for the Second Year. 


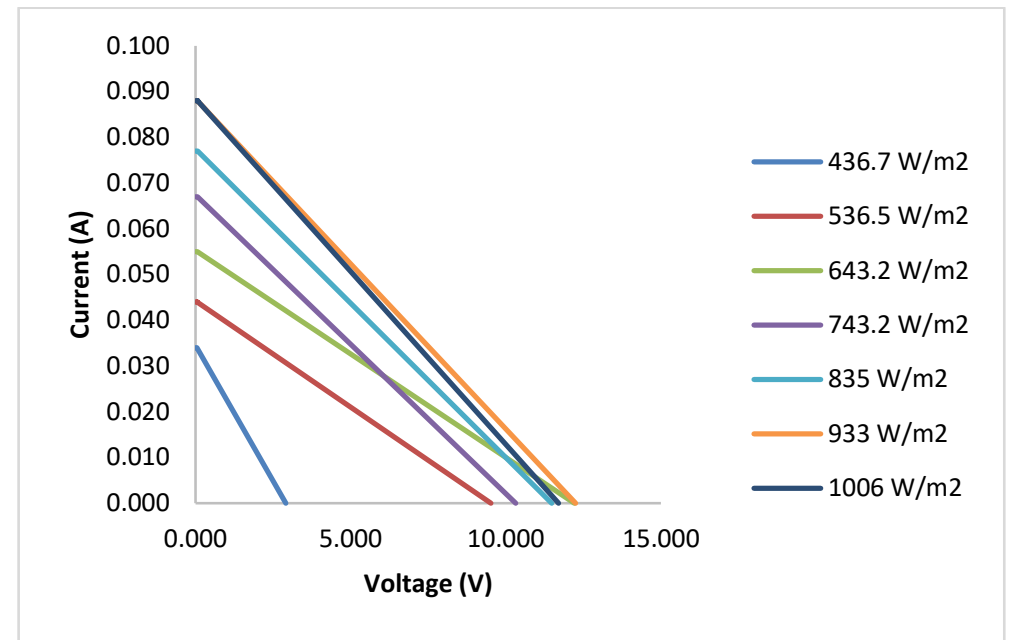

Fig. 3:I-V Characteristics of the Amorphous Silicon Module as A Function of Global Irradiance for the Third Year.

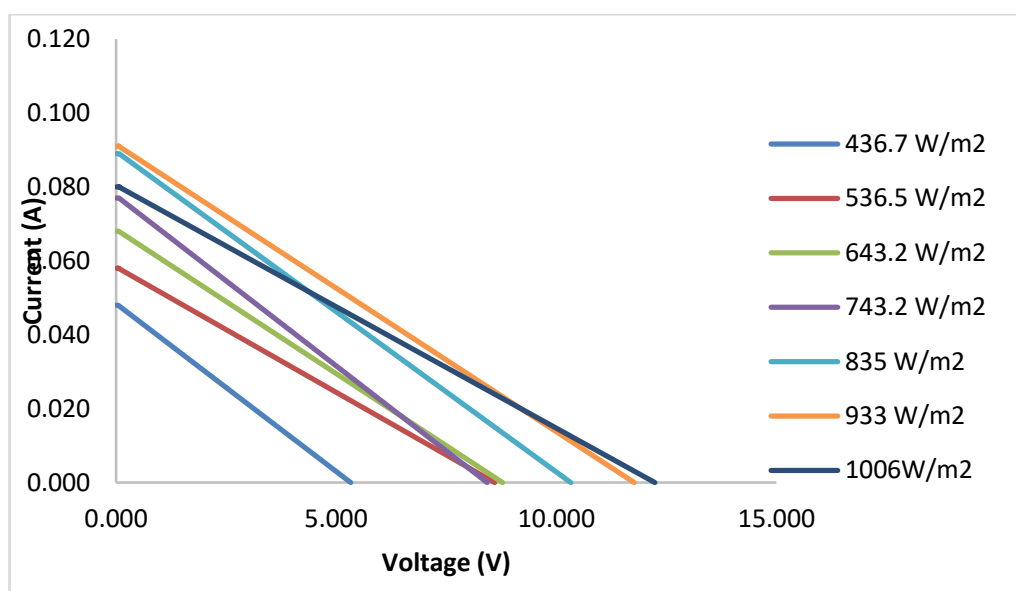

Fig. 4:I-V Characteristics of the Amorphous Silicon Module as A Function of Global Irradiance for the Fourth Year.

Annual hourly average values of the module performance variables and ambient parameters for the four years data collected are shown in Tables $1-4$ while the annual hourly average plots of the performance variables are shown in Figures $5-12$.

Table 1:Annual Hourly Averages of Performance Variables and Ambient Parameters for Year One (2015)

\begin{tabular}{|c|c|c|c|c|c|c|c|c|c|}
\hline T(Hours) & $\mathrm{WS}(\mathrm{m} / \mathrm{s})$ & $\mathrm{T}_{\mathrm{a}}\left({ }^{0} \mathrm{C}\right)$ & $\mathrm{RH}(\%)$ & $\mathrm{T}_{\bmod }\left({ }^{0} \mathrm{C}\right)$ & $\mathrm{H}_{\mathrm{g}}\left(\mathrm{W} / \mathrm{m}^{2}\right)$ & $\mathrm{V}_{\mathrm{oc}}(\mathrm{v})$ & $\mathrm{I}_{\mathrm{sc}}(\mathrm{A})$ & $\mathrm{P}(\mathrm{W})$ & $\mathrm{P}_{\max }(\mathrm{W})$ \\
\hline 9 AM & 1.94 & 21.3 & 56.6 & 30.2 & 419 & 0.37 & 0.029 & 0.019 & 0.022 \\
\hline $10 \mathrm{AM}$ & 1.98 & 23.1 & 54.5 & 32.7 & 561 & 2.01 & 0.039 & 0.105 & 0.142 \\
\hline $11 \mathrm{AM}$ & 1.87 & 24.5 & 51.9 & 35.0 & 661 & 4.74 & 0.045 & 0.253 & 0.355 \\
\hline 12 PM & 1.80 & 25.5 & 49.4 & 36.9 & 705 & 6.79 & 0.047 & 0.362 & 0.534 \\
\hline $1 \mathrm{PM}$ & 1.66 & 26.4 & 46.7 & 38.2 & 698 & 7.16 & 0.048 & 0.383 & 0.563 \\
\hline 2 PM & 1.61 & 27.1 & 45.1 & 38.3 & 611 & 5.89 & 0.046 & 0.316 & 0.433 \\
\hline 3 PM & 1.50 & 27.3 & 43.8 & 37.7 & 489 & 2.12 & 0.043 & 0.121 & 0.147 \\
\hline 4 PM & 1.40 & 27.4 & 43.4 & 36.2 & 318 & 0.07 & 0.031 & 0.013 & 0.013 \\
\hline $5 \mathrm{PM}$ & 1.15 & 26.5 & 44.1 & 33.6 & 137 & 0.02 & 0.014 & 0.004 & 0.005 \\
\hline $6 \mathrm{PM}$ & 0.94 & 25.3 & 45.6 & 31.8 & 58 & 0.01 & 0.006 & 0.000 & 0.000 \\
\hline
\end{tabular}

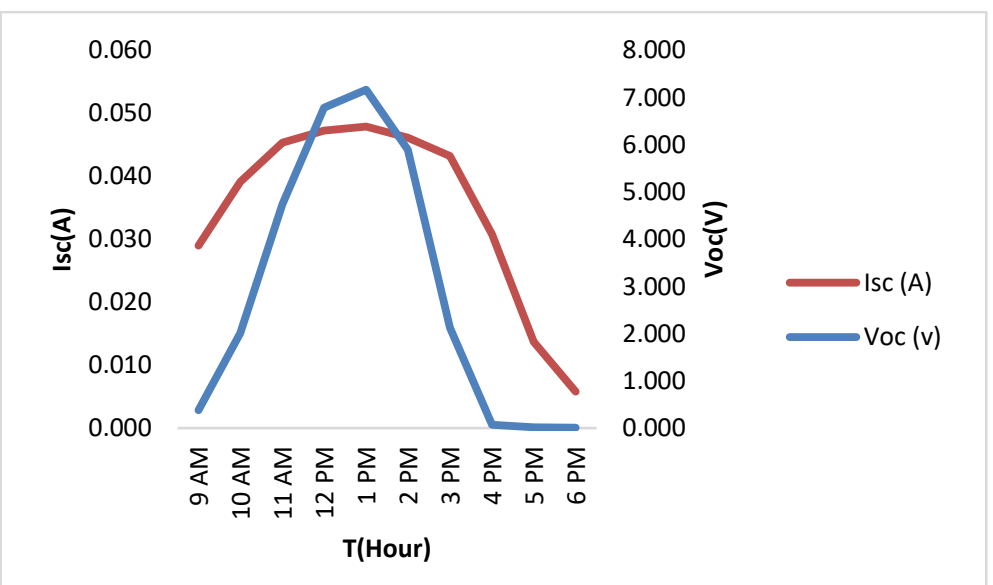

Fig. 5:Annual Hourly Average Plot of Short-Circuit Current and Open Circuit-Voltage for the Amorphous Module in Year 2015. 


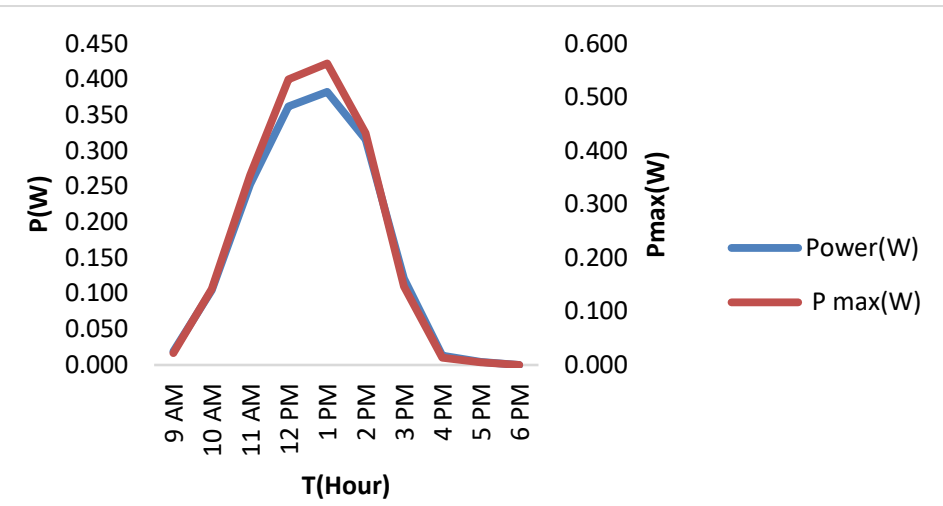

Fig. 6:Annual Hourly Average Plot of Power Output and Maximum Power for the Amorphous Module in Year 2015.

Table 2:Annual Hourly Averages of Performance Variables and Ambient Parameters for Year Two (2016)

\begin{tabular}{|c|c|c|c|c|c|c|c|c|c|}
\hline T(Hours) & $\mathrm{WS}(\mathrm{m} / \mathrm{s})$ & $\mathrm{T}_{\mathrm{a}}\left({ }^{0} \mathrm{C}\right)$ & $\mathrm{RH}(\%)$ & $\mathrm{T}_{\text {mod }}\left({ }^{0} \mathrm{C}\right)$ & $\mathrm{H}_{\mathrm{g}}\left(\mathrm{W} / \mathrm{m}^{2}\right)$ & $\mathrm{V}_{\mathrm{oc}}(\mathrm{v})$ & $\mathrm{I}_{\mathrm{sc}}(\mathrm{A})$ & $\mathrm{P}(\mathrm{W})$ & $\mathrm{P}_{\max }(\mathrm{W})$ \\
\hline $9 \mathrm{AM}$ & 1.86 & 27.6 & 60.1 & 30.0 & 414 & 0.11 & 0.006 & 0.008 & 0.010 \\
\hline $10 \mathrm{AM}$ & 1.84 & 29.1 & 56.4 & 32.8 & 566 & 1.93 & 0.024 & 0.158 & 0.203 \\
\hline $11 \mathrm{AM}$ & 1.76 & 30.5 & 52.9 & 35.3 & 663 & 4.71 & 0.046 & 0.425 & 0.516 \\
\hline $12 \mathrm{PM}$ & 1.71 & 31.6 & 49.9 & 37.2 & 723 & 6.03 & 0.055 & 0.557 & 0.671 \\
\hline $1 \mathrm{PM}$ & 1.60 & 32.4 & 47.4 & 38.3 & 708 & 5.77 & 0.056 & 0.519 & 0.642 \\
\hline $2 \mathrm{PM}$ & 1.53 & 32.9 & 45.4 & 38.6 & 641 & 3.76 & 0.047 & 0.290 & 0.390 \\
\hline $3 \mathrm{PM}$ & 1.45 & 33.1 & 44.6 & 37.9 & 518 & 0.82 & 0.030 & 0.046 & 0.082 \\
\hline $4 \mathrm{PM}$ & 1.31 & 33.0 & 44.4 & 36.4 & 338 & 0.03 & 0.019 & 0.002 & 0.003 \\
\hline $6 \mathrm{PM}$ & 0.92 & 31.4 & 49.3 & 31.5 & 61 & 0.01 & 0.004 & 0.001 & 0.001 \\
\hline
\end{tabular}

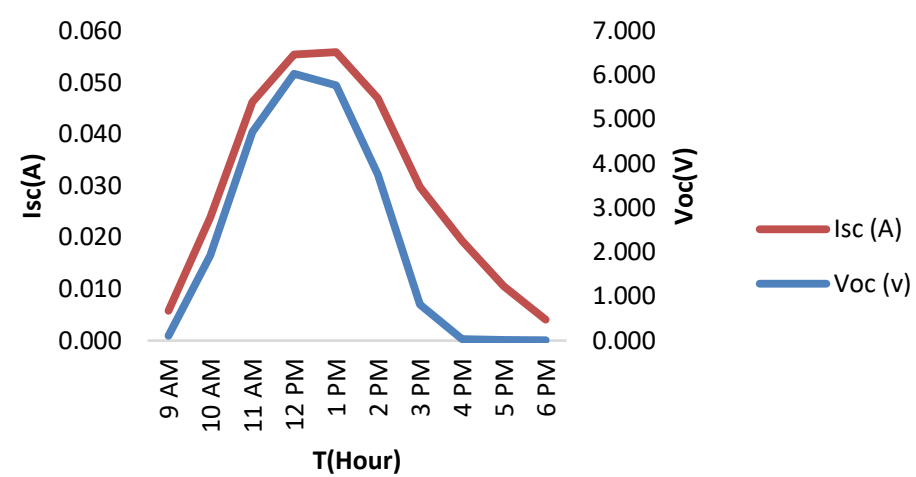

Fig. 7:Annual Hourly Average Plot of Short-Circuit Current and Open Circuit-Voltage for the Amorphous Module in Year 2016.

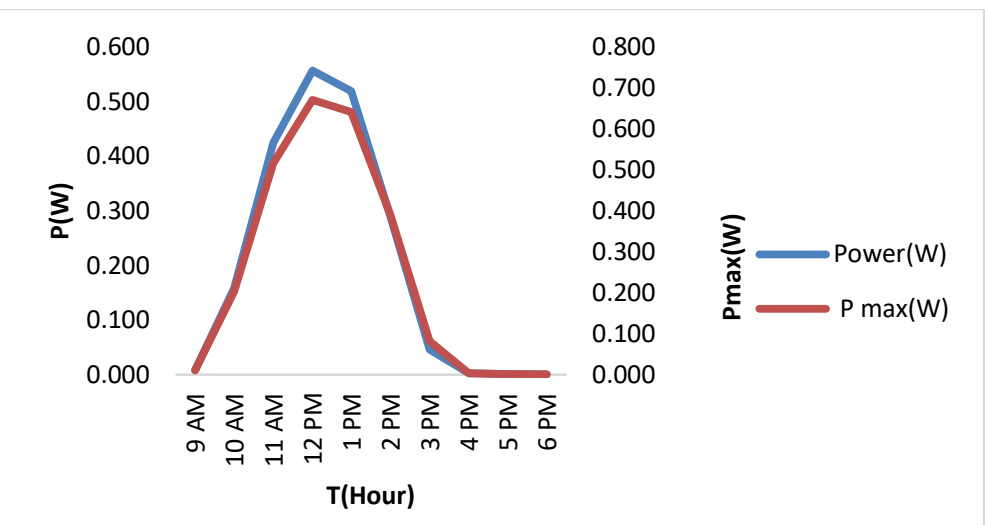

Fig. 8: Annual Hourly Average Plot of Power Output and Maximum Power for the Amorphous Module in Year 2016.

Table 3:Annual Hourly Averages of Performance Variables and Ambient Parameters for Year Three (2017)

\begin{tabular}{|c|c|c|c|c|c|c|c|c|c|}
\hline $\mathrm{T}$ (Hours) & $\mathrm{WS}(\mathrm{m} / \mathrm{s})$ & $\mathrm{T}_{\mathrm{a}}\left({ }^{0} \mathrm{C}\right)$ & $\mathrm{RH}(\%)$ & $\mathrm{T}_{\bmod }\left({ }^{0} \mathrm{C}\right)$ & $\mathrm{H}_{\mathrm{g}}\left(\mathrm{W} / \mathrm{m}^{2}\right)$ & $\mathrm{V}_{\mathrm{oc}}(\mathrm{v})$ & $\mathrm{I}_{\mathrm{sc}}(\mathrm{A})$ & $\mathrm{P}(\mathrm{W})$ & $\mathrm{P}_{\max }(\mathrm{W})$ \\
\hline $9 \mathrm{AM}$ & 1.64 & 28.5 & 56.6 & 31.0 & 409 & 0.13 & 0.003 & 0.009 & 0.013 \\
\hline $10 \mathrm{AM}$ & 1.63 & 30.1 & 53.2 & 33.9 & 552 & 1.50 & 0.014 & 0.148 & 0.183 \\
\hline $11 \mathrm{AM}$ & 1.54 & 31.5 & 50.0 & 36.4 & 648 & 3.17 & 0.023 & 0.362 & 0.416 \\
\hline $1 \mathrm{PM}$ & 1.41 & 33.3 & 45.0 & 39.4 & 684 & 3.84 & 0.048 & 0.483 & 0.547 \\
\hline $2 \mathrm{PM}$ & 1.27 & 33.7 & 43.2 & 39.4 & 614 & 2.67 & 0.041 & 0.316 & 0.363 \\
\hline $3 \mathrm{PM}$ & 1.17 & 33.9 & 42.1 & 38.6 & 492 & 0.69 & 0.023 & 0.069 & 0.082 \\
\hline
\end{tabular}




\begin{tabular}{|c|c|c|c|c|c|c|c|c|c|}
\hline $4 \mathrm{PM}$ & 1.07 & 33.7 & 42.3 & 36.9 & 322 & 0.03 & 0.013 & 0.003 & 0.003 \\
\hline $5 \mathrm{PM}$ & 0.89 & 33.0 & 44.3 & 34.0 & 144 & 0.01 & 0.003 & 0.001 & 0.001 \\
\hline $6 \mathrm{PM}$ & 0.75 & 32.2 & 47.0 & 32.0 & 62 & 0.01 & 0.005 & 0.001 & 0.001 \\
\hline
\end{tabular}

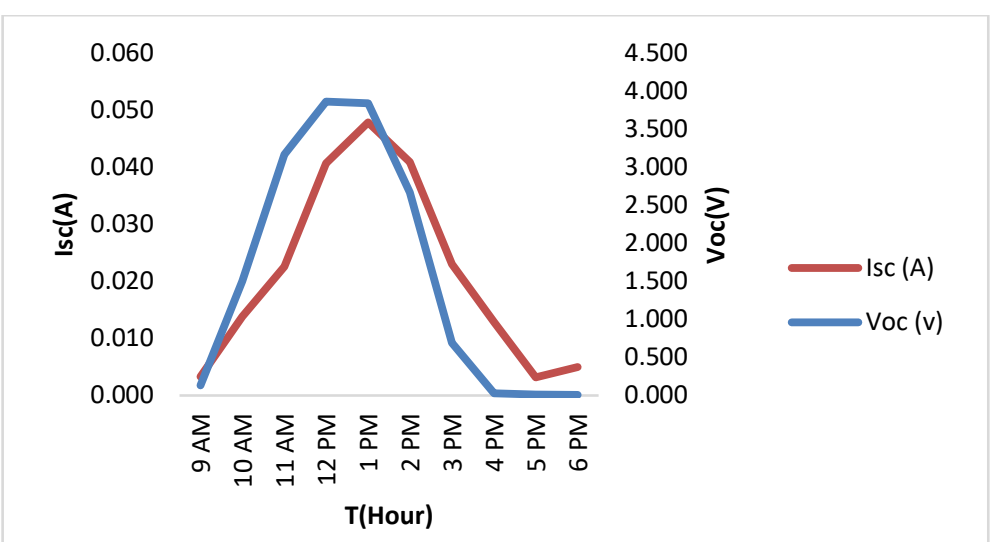

Fig. 9:Annual Hourly Average Plot of Short-Circuit Current and Open Circuit-Voltage for the Amorphous Module in Year 2017.

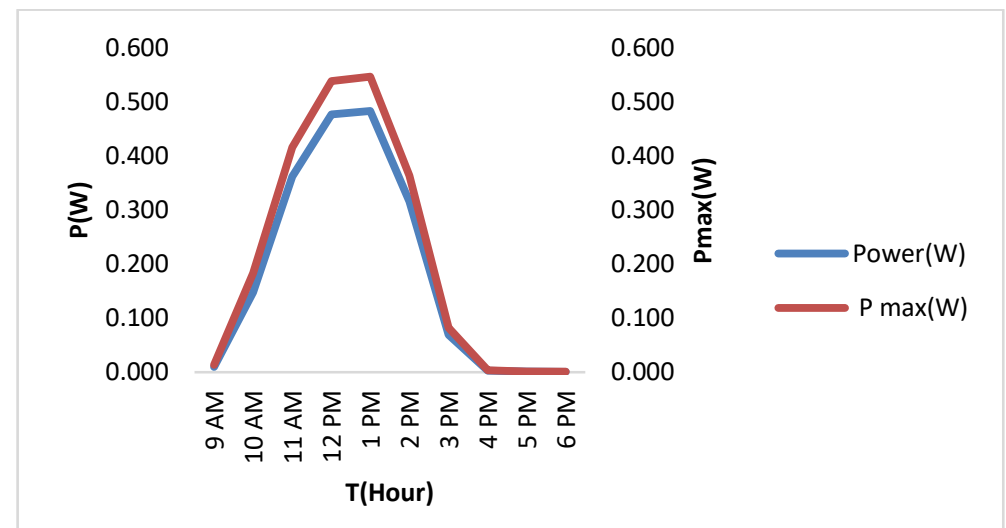

Fig. 10:Annual Hourly Average Plot of Power Output and Maximum Power for the Amorphous Module in Year 2017.

Table 4:Annual Hourly Averages of Performance Variables and Ambient Parameters for Year Four (2018)

\begin{tabular}{|c|c|c|c|c|c|c|c|c|c|}
\hline T(Hours) & $\mathrm{WS}(\mathrm{m} / \mathrm{s})$ & $\mathrm{T}_{\mathrm{a}}\left({ }^{0} \mathrm{C}\right)$ & $\mathrm{RH}(\%)$ & $\mathrm{T}_{\bmod }\left({ }^{0} \mathrm{C}\right)$ & $\mathrm{H}_{\mathrm{g}}\left(\mathrm{W} / \mathrm{m}^{2}\right)$ & $\mathrm{V}_{\mathrm{oc}}(\mathrm{v})$ & $\mathrm{I}_{\mathrm{sc}}(\mathrm{A})$ & $\mathrm{P}(\mathrm{W})$ & $\mathrm{P}_{\max }(\mathrm{W})$ \\
\hline 9 AM & 1.31 & 28.9 & 64.8 & 30.4 & 380 & 0.13 & 0.000 & 0.008 & 0.011 \\
\hline $10 \mathrm{AM}$ & 1.37 & 30.5 & 60.8 & 33.3 & 519 & 1.43 & 0.001 & 0.089 & 0.130 \\
\hline $11 \mathrm{AM}$ & 1.21 & 32.1 & 56.9 & 36.1 & 624 & 3.41 & 0.004 & 0.228 & 0.313 \\
\hline $12 \mathrm{PM}$ & 1.15 & 33.3 & 53.7 & 38.0 & 670 & 4.22 & 0.025 & 0.346 & 0.432 \\
\hline $1 \mathrm{PM}$ & 1.07 & 34.0 & 50.7 & 39.2 & 674 & 4.26 & 0.034 & 0.367 & 0.464 \\
\hline $2 \mathrm{PM}$ & 0.97 & 34.3 & 48.3 & 39.3 & 603 & 2.78 & 0.026 & 0.213 & 0.285 \\
\hline 3 PM & 0.89 & 34.3 & 47.2 & 38.4 & 474 & 0.44 & 0.008 & 0.025 & 0.043 \\
\hline $4 \mathrm{PM}$ & 0.72 & 34.0 & 46.8 & 36.7 & 316 & 0.02 & 0.001 & 0.002 & 0.002 \\
\hline $5 \mathrm{PM}$ & 0.61 & 33.3 & 48.7 & 33.7 & 143 & 0.01 & 0.001 & 0.001 & 0.001 \\
\hline $6 \mathrm{PM}$ & 0.48 & 32.5 & 51.0 & 31.6 & 62 & 0.01 & 0.002 & 0.001 & 0.001 \\
\hline
\end{tabular}

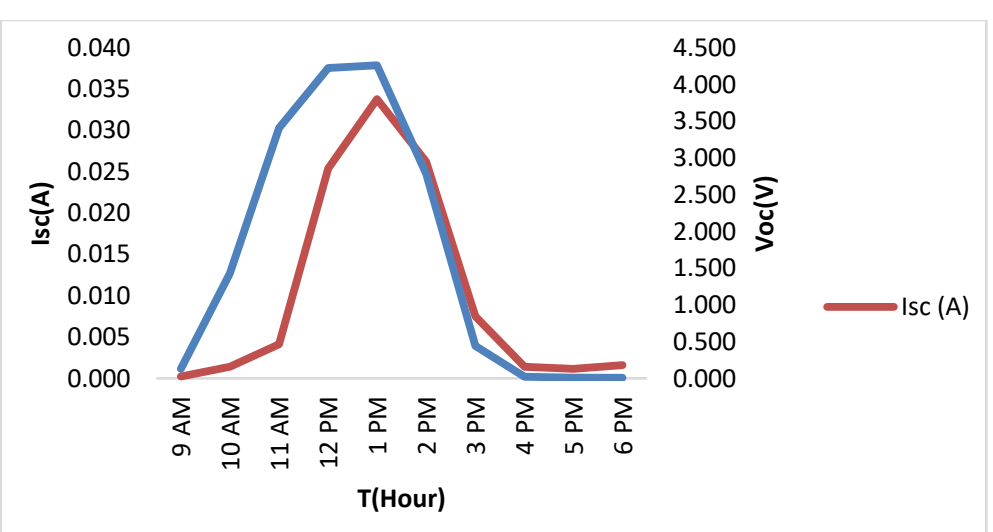

Fig. 11:Annual Hourly Average Plot of Short-Circuit Current and Open Circuit-Voltage for the Amorphous Module in Year 2018. 


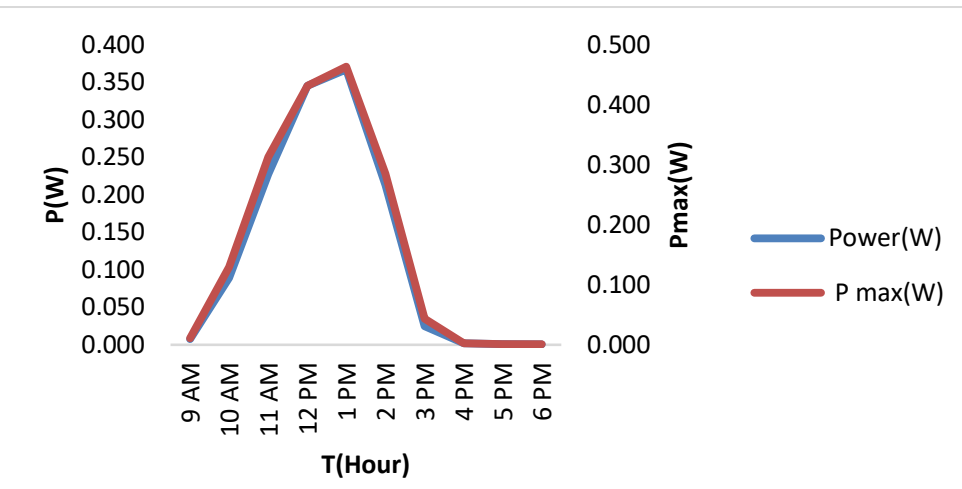

Fig. 12:Annual Hourly Average Plot of Power Output and Maximum Power for the Amorphous Module in Year 2018

It was discovered from tables 1 - 4 that all performance variables of the amorphous module are seen to peak between the hours of $12 \mathrm{pm}$ and $1 \mathrm{pm}$ local time for the four years of study. For the ambient parameters, solar irradiance $(\mathrm{Hg})$ peak time is at $12 \mathrm{pm}$ while ambient temperature $\left(\mathrm{T}_{\mathrm{a}}\right.$ ) peaked between $2 \mathrm{pm}$ and $4 \mathrm{pm}$ local time for the four years of study respectively. Similarly, for wind speed (WS), its peak time is seen between 9am and 10am while relative humidity (RH) was equally observed to peak at 9am local time throughout the four years in the minna local environment. Also, it was closely observed that module temperature ( $\left.\mathrm{T}_{\mathrm{mod}}\right)$ peaked at $2 \mathrm{pm}$ local time throughout the period of study as shown in tables $1-4$.

Monthly hourly averages of the performance variables (open circuit voltage, short-circuit current, power output, maximum power) are investigated using four years data collected and the plots for a typical dry season month (January) and a typical rainy season month (August) for each year $(2015-2018)$ are shown in Figures $13-27$.

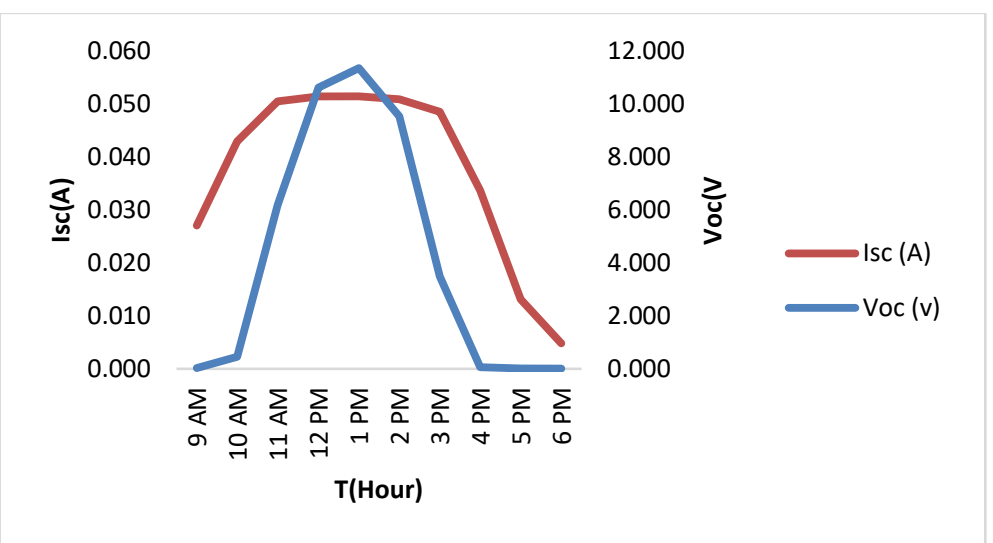

Fig. 13:Hourly Averages Variation of Short-Circuit Current and Open-Circuit Voltage of Amorphous Silicon Module as A Function of Time for the Month of January 2015

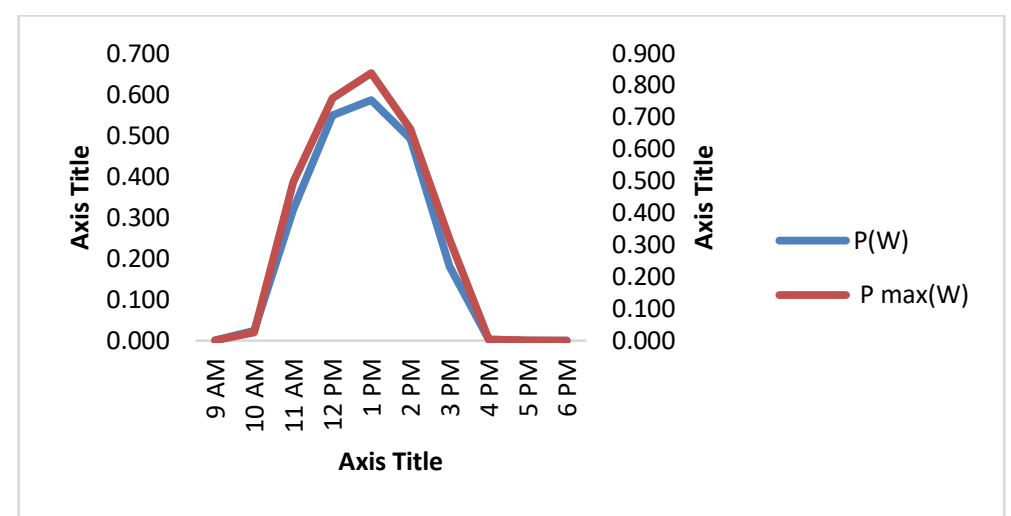

Fig. 14: Hourly Averages Variation of Power Output and Maximum Power of Amorphous Silicon Module as A Function of Time for the Month of January 2015 . 


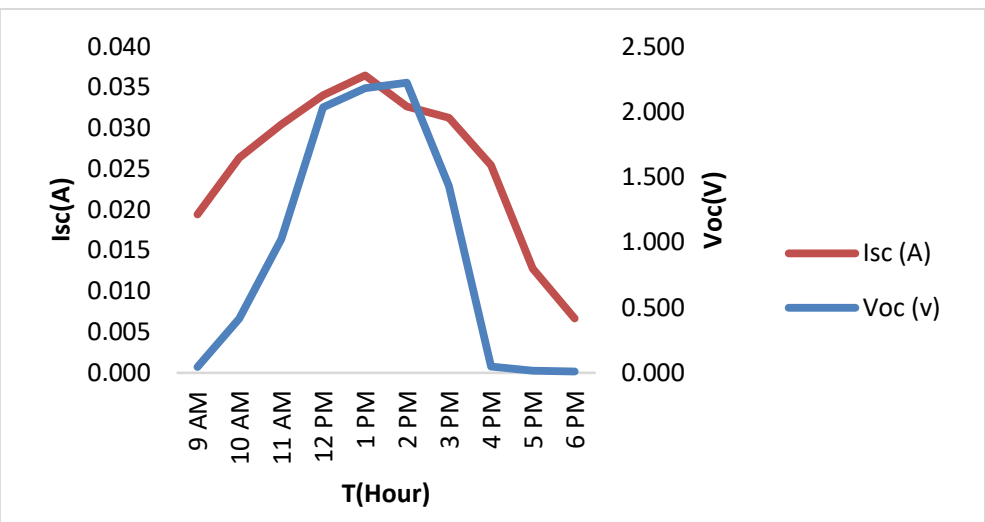

Fig. 15:Hourly Averages Variation of Short-Circuit Current and Open-Circuit Voltage of Amorphous Silicon Module as A Function of Time for the Month of August 2015.

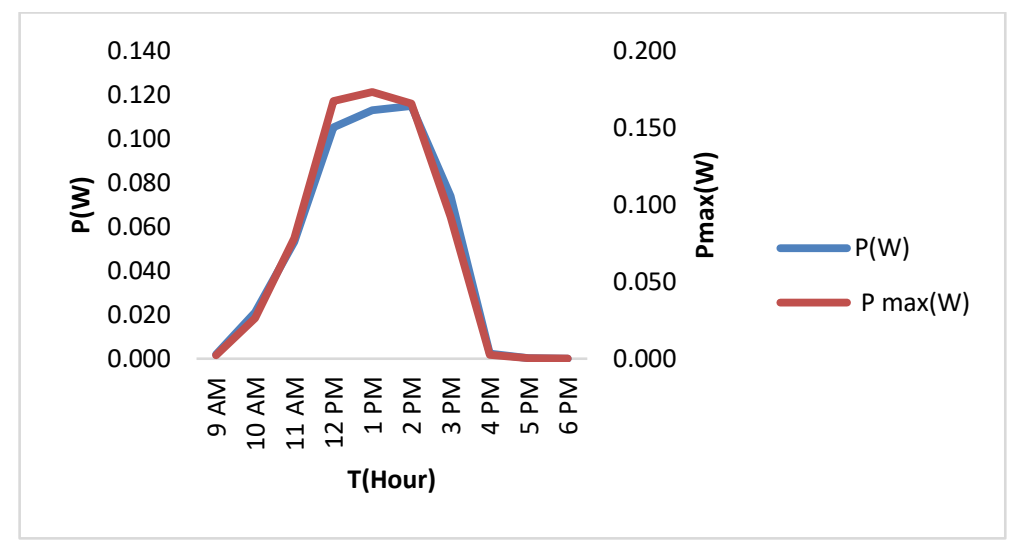

Fig. 16:Hourly Averages Variation of Power Output and Maximum Power of Amorphous Silicon Module as A Function of Time for the Month of August 2015.

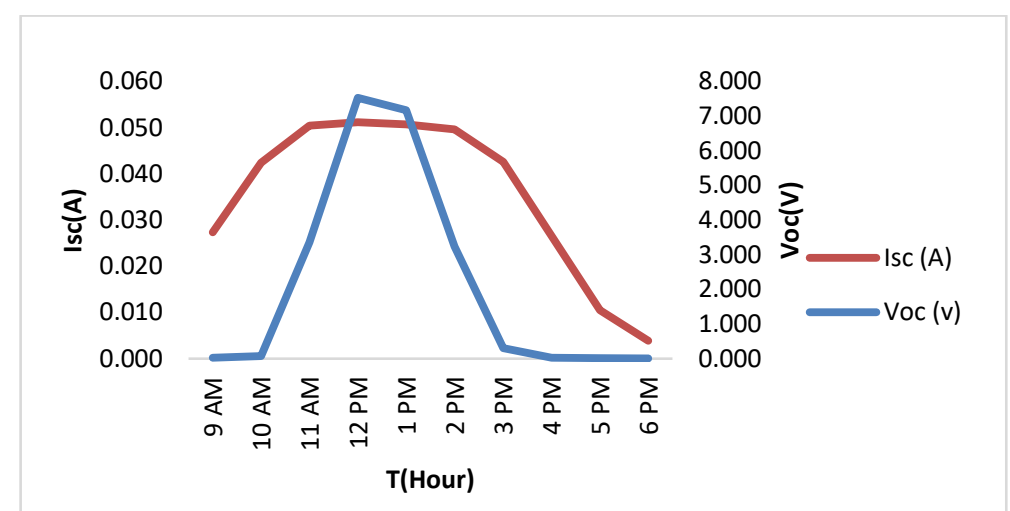

Fig. 17:Hourly Averages Variation of Short-Circuit Current and Open-Circuit Voltage of Amorphous Silicon Module as A Function of Time for the Month of January 2016

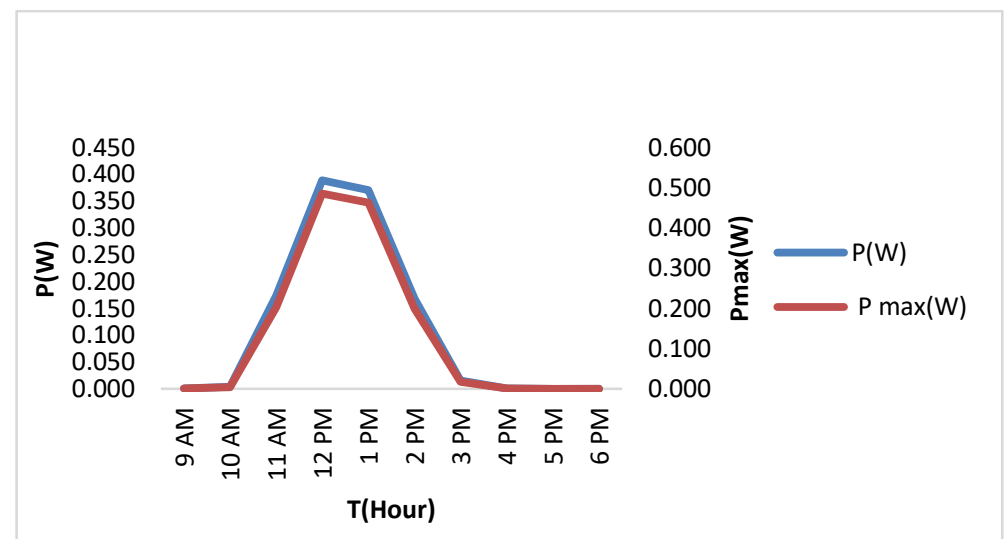

Fig. 18:Hourly Averages Variation of Power Output and Maximum Power of Amorphous Silicon Module as A Function of Time for the Month of January 2016. 


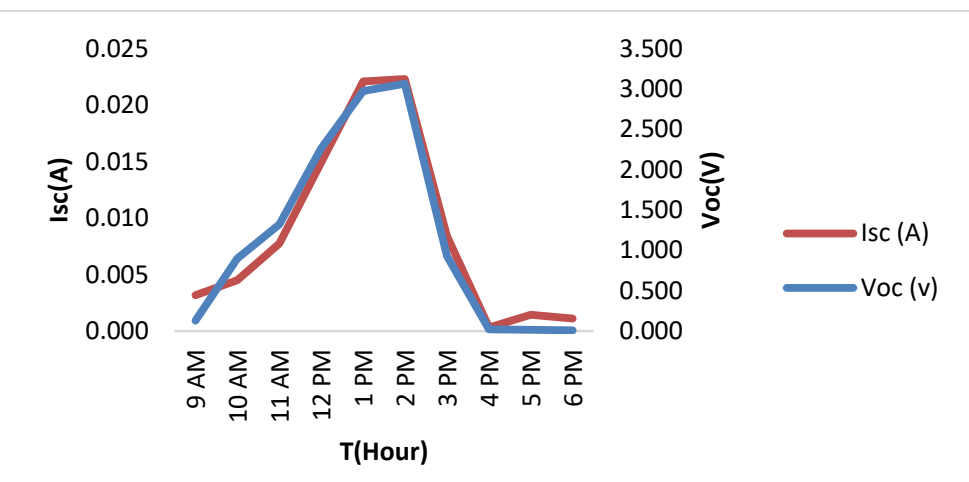

Fig. 19:Hourly Averages Variation of Short-Circuit Current and Open-Circuit Voltage of Amorphous Silicon Module as A Function of Time for the Month of August 2016

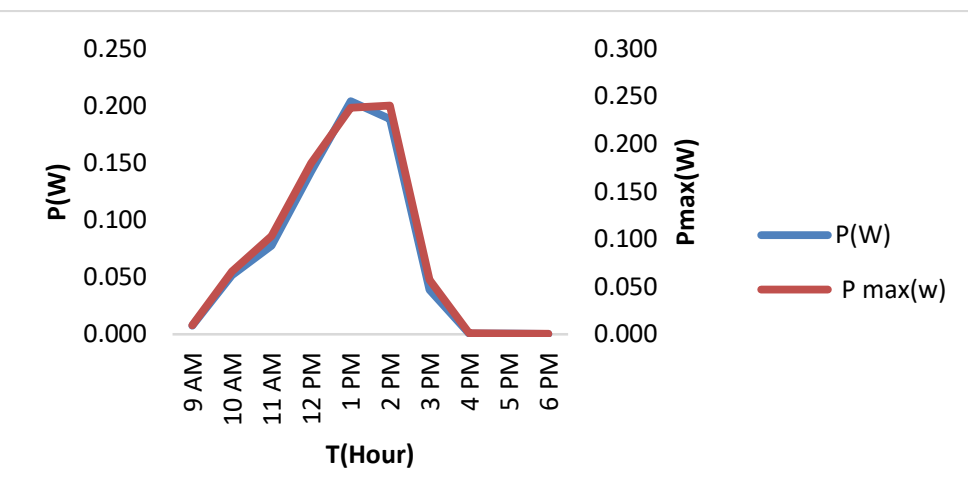

Fig. 20:Hourly Averages Variation of Power Output and Maximum Power of Amorphous Silicon Module as A Function of Time for the Month of August 2016 .

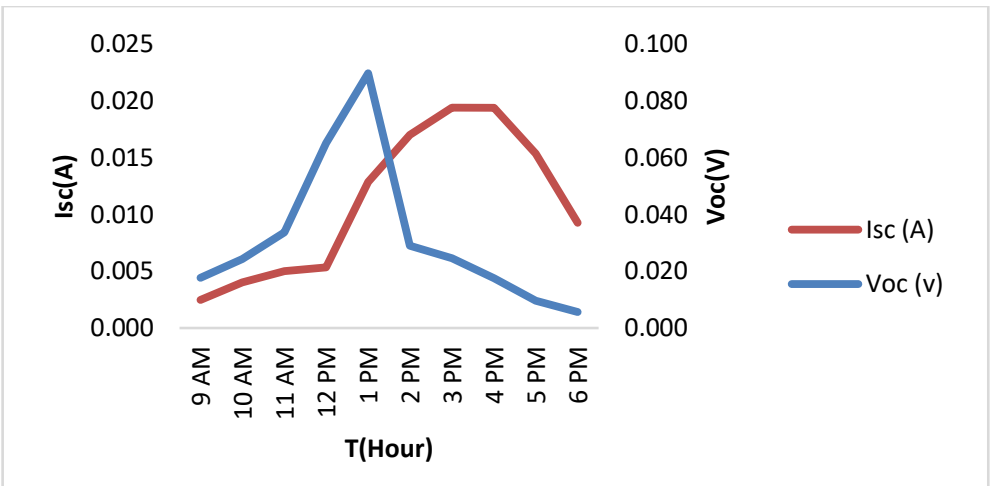

Fig. 21:Hourly Averages Variation of Short-Circuit Current and Open-Circuit Voltage of Amorphous Silicon Module as A Function of Time for the Month of January2017.

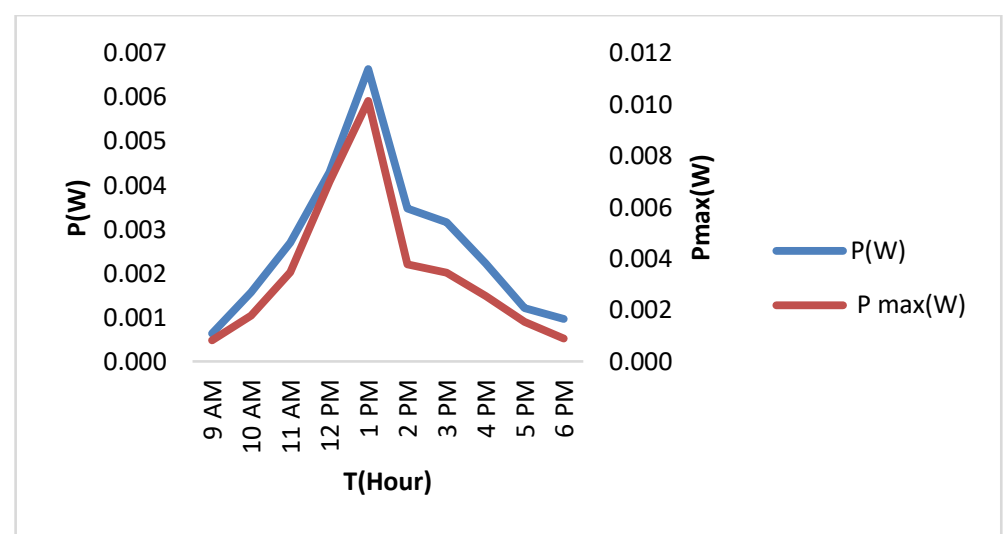

Fig. 22:Hourly Averages Variation of Power Output and Maximum Power of Amorphous Silicon Module as A Function of Time for the Month of January 2017. 


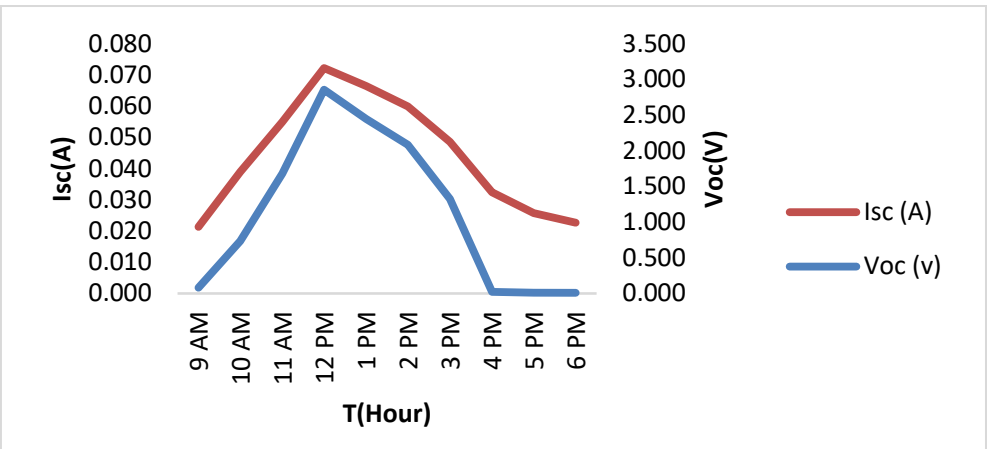

Fig. 23:Hourly Averages Variation of Short-Circuit Current and Open-Circuit Voltage of Amorphous Silicon Module as A Function of Time for the Month of August 2017.

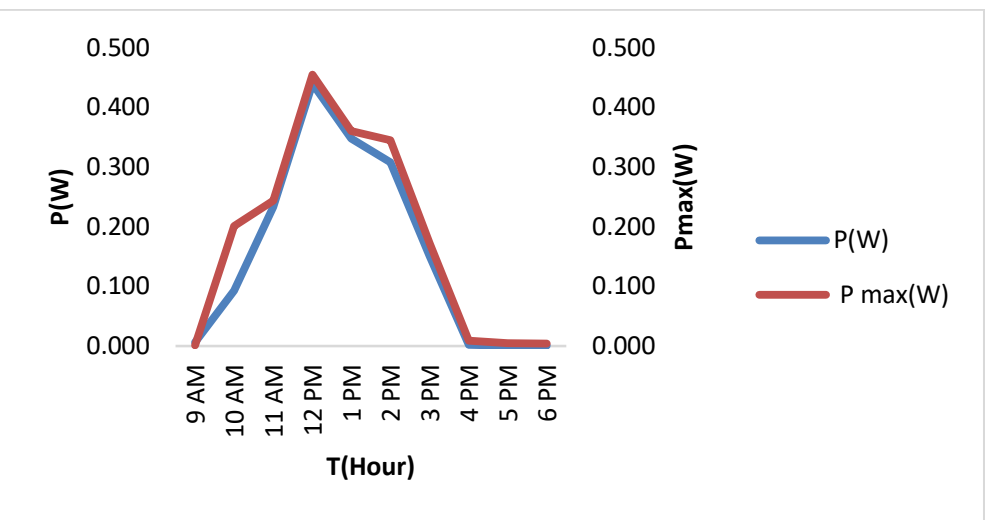

Fig. 24:Hourly Averages Variation of Power Output and Maximum Power of Amorphous Silicon Module as A Function of Time for the Month of August 2017.

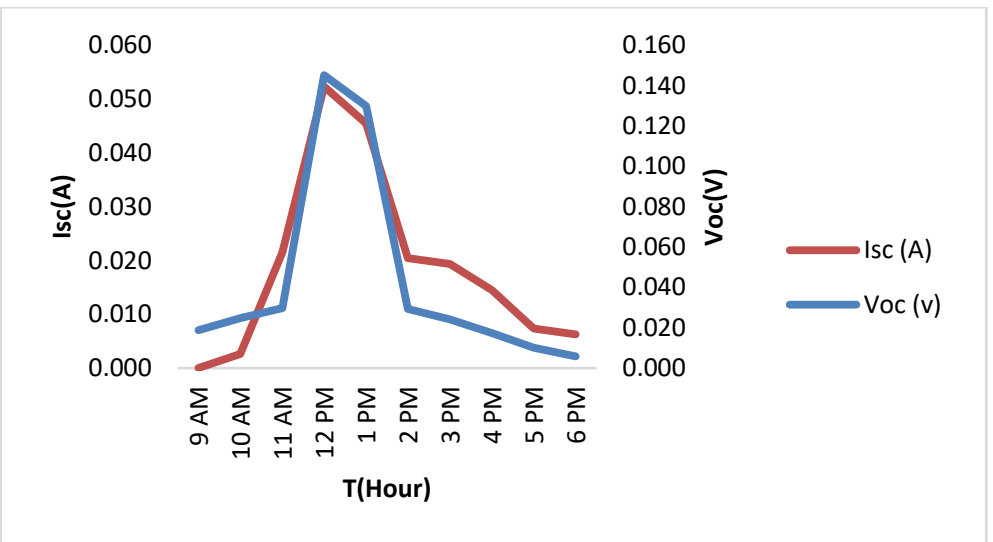

Fig. 25:Hourly Averages Variation of Short-Circuit Current and Open-Circuit Voltage of Amorphous Silicon Module as A Function of Time for the Month of January 2018.

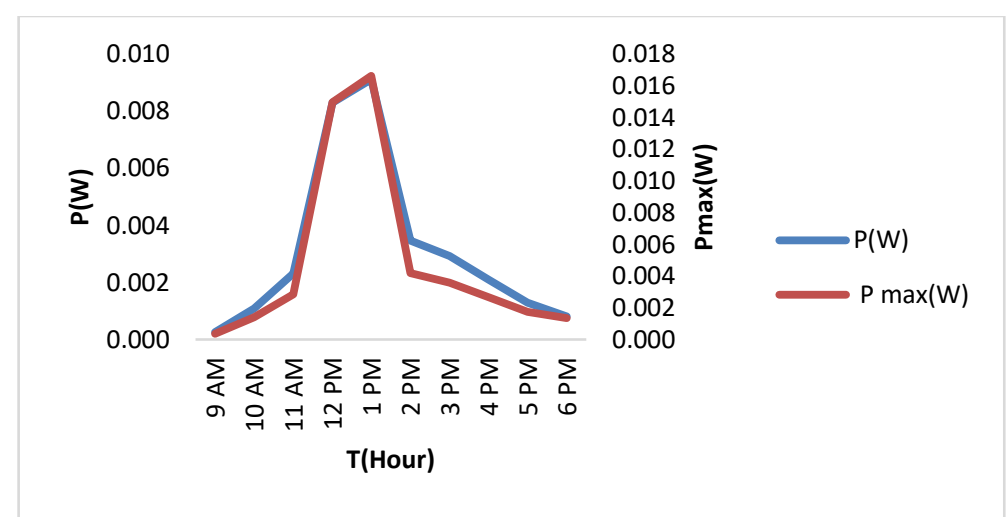

Fig. 26:Hourly Averages Variation of Power Output and Maximum Power of Amorphous Silicon Module as A Function of Time for the Month of January 2018. 


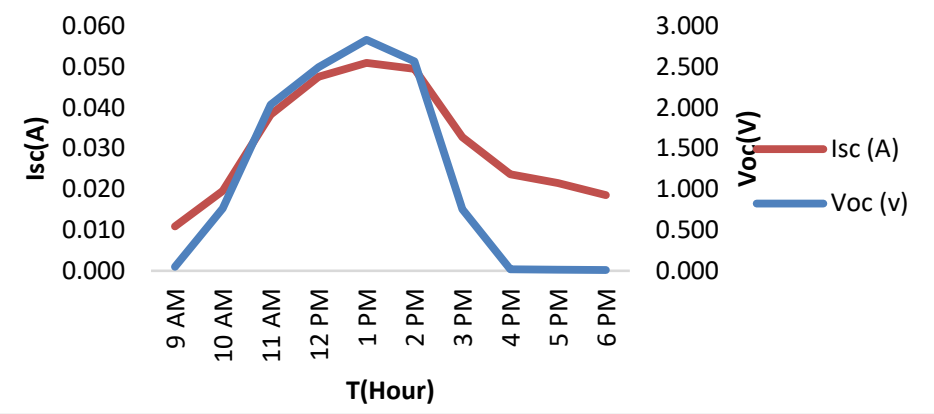

Fig. 27:Hourly Averages Variation of Short-Circuit Current and Open-Circuit Voltage of Amorphous Silicon Module as A Function of Time for the Month of August 2018.

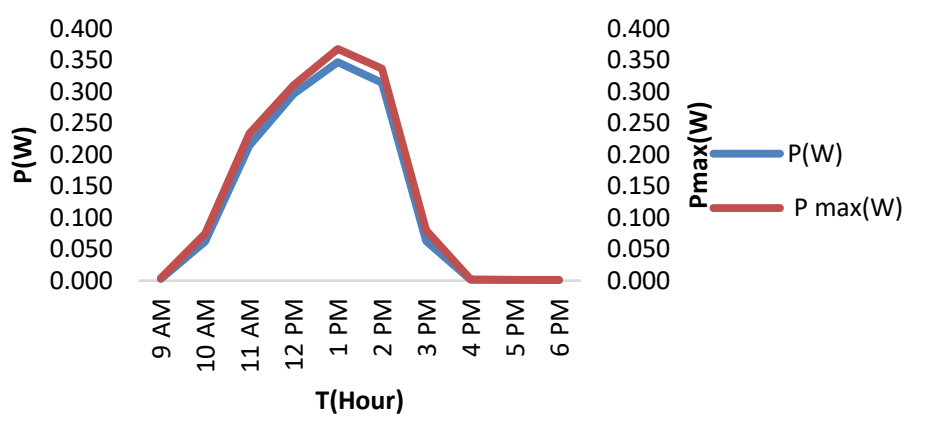

Fig. 28:Hourly Averages Variation of Power Output and Maximum Power of Amorphous Silicon Module as A Function of Time for the Month of August 2018

It was observed from the plots of Figures $13-28$ that for the four years of study, the amorphous silicon photovoltaic module performance variables peaked at the afternoon time for the two climatic seasons, that is, between 12:00pm and 2:00pm local time which is usually the peak time for amorphous silicon module and this has confirmed the work of [9] which states that amorphous silicon module performance variables are usually less affected by high temperature.

The performance responses of amorphous silicon photovoltaic module for the period of four years study at different levels of irradiance (global irradiance) were summarized in Table 5. Fill factor and efficiency at the different irradiance levels for the amorphous module were computed and inserted.

Table 5:Performance Response for Year 2015 at Different Irradiance Levels

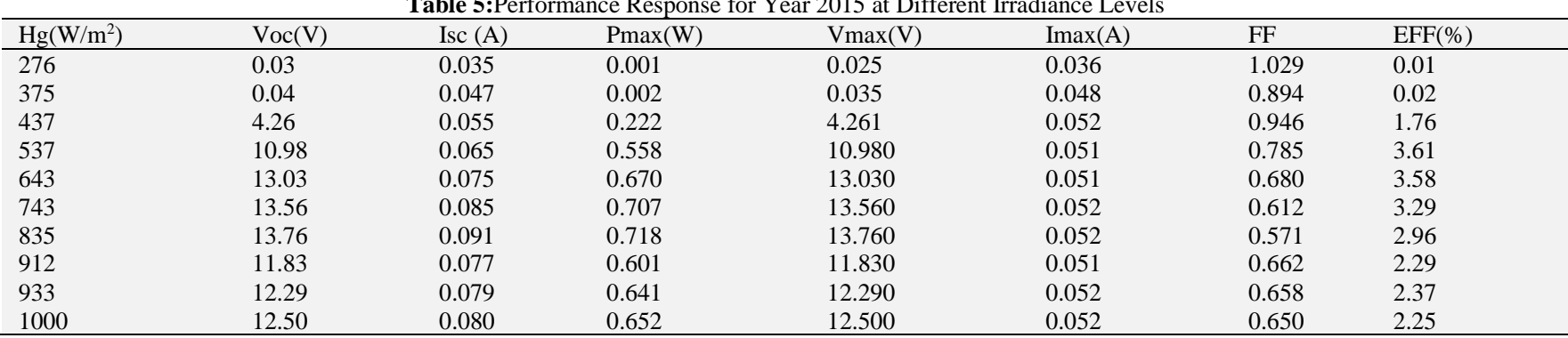

$\mathrm{T}_{\text {mod }}=37^{\circ} \mathrm{C}, \mathrm{MPR}=0.07, \mathrm{P}_{\max }(\%)=6.52 \%$

Table 6:Performance Response for Year 2016 at Different Irradiance Levels

\begin{tabular}{|c|c|c|c|c|c|c|c|}
\hline $\mathrm{Hg}\left(\mathrm{W} / \mathrm{m}^{2}\right)$ & $\operatorname{Voc}(\mathrm{V})$ & Isc (A) & $\operatorname{Pmax}(\mathrm{W})$ & $\mathrm{Vmax}(\mathrm{V})$ & $\operatorname{Imax}(\mathrm{A})$ & $\mathrm{FF}$ & $\mathrm{EFF}(\%)$ \\
\hline 276 & 0.03 & 0.039 & 0.001 & 0.040 & 0.013 & 0.529 & 0.01 \\
\hline 375 & 0.03 & 0.039 & 0.001 & 0.030 & 0.039 & 1.000 & 0.01 \\
\hline 437 & 3.31 & 0.035 & 0.109 & 3.310 & 0.033 & 0.943 & 0.86 \\
\hline 537 & 7.82 & 0.045 & 0.044 & 10.820 & 0.004 & 0.126 & 0.29 \\
\hline 643 & 8.88 & 0.055 & 1.661 & 8.880 & 0.187 & 3.400 & 8.94 \\
\hline 743 & 8.11 & 0.065 & 0.368 & 5.841 & 0.063 & 0.698 & 1.71 \\
\hline 835 & 8.74 & 0.075 & 0.559 & 8.740 & 0.064 & 0.853 & 2.32 \\
\hline 912 & 10.30 & 0.075 & 0.680 & 10.300 & 0.066 & 0.880 & 2.58 \\
\hline 933 & 11.21 & 0.085 & 2.674 & 12.210 & 0.219 & 2.806 & 9.92 \\
\hline 1000 & 11.61 & 0.089 & 2.186 & 11.750 & 0.186 & 2.115 & 7.56 \\
\hline
\end{tabular}

$\mathrm{T}_{\text {mod }}=37^{\circ} \mathrm{C}, \mathrm{MPR}=0.23, \mathrm{P}_{\max }(\%)=21.86 \%$

Table 7:Performance Response for Year 2017 at Different Irradiance Levels

\begin{tabular}{|c|c|c|c|c|c|c|c|}
\hline $\mathrm{Hg}\left(\mathrm{W} / \mathrm{m}^{2}\right)$ & Voc(V) & Isc (A) & $\operatorname{Pmax}(\mathrm{W})$ & $\mathrm{Vmax}(\mathrm{V})$ & $\operatorname{Imax}(\mathrm{A})$ & $\mathrm{FF}$ & $\mathrm{EFF}(\%)$ \\
\hline 276 & 0.02 & 0.023 & 0.003 & 0.020 & 0.152 & 6.609 & 0.04 \\
\hline 375 & 0.03 & 0.029 & 0.004 & 0.025 & 0.167 & 5.759 & 0.04 \\
\hline 437 & 2.91 & 0.034 & 0.422 & 2.910 & 0.145 & 4.265 & 3.34 \\
\hline
\end{tabular}




\begin{tabular}{|c|c|c|c|c|c|c|c|}
\hline 537 & 9.52 & 0.044 & 0.733 & 9.520 & 0.077 & 1.750 & 4.72 \\
\hline 643 & 12.21 & 0.055 & 1.233 & 12.210 & 0.101 & 1.836 & 6.64 \\
\hline 743 & 10.32 & 0.067 & 1.744 & 10.320 & 0.169 & 2.522 & 8.12 \\
\hline 835 & 11.48 & 0.077 & 1.573 & 11.480 & 0.137 & 1.779 & 6.52 \\
\hline 912 & 11.74 & 0.071 & 2.160 & 11.740 & 0.184 & 2.592 & 8.20 \\
\hline 933 & 12.45 & 0.088 & 2.303 & 12.450 & 0.185 & 2.102 & 8.54 \\
\hline 1000 & 11.70 & 0.088 & 2.078 & 11.740 & 0.177 & 2.018 & 7.19 \\
\hline
\end{tabular}

$\mathrm{T}_{\text {mod }}=38.6^{\circ} \mathrm{C}, \mathrm{MPR}=0.22, \mathrm{P}_{\max }(\%)=20.78 \%$

Table 8:Performance Response for Year 2018 at Different Irradiance Levels

\begin{tabular}{|c|c|c|c|c|c|c|c|}
\hline $\mathrm{Hg}\left(\mathrm{W} / \mathrm{m}^{2}\right)$ & $\operatorname{Voc}(\mathrm{V})$ & Isc (A) & $\operatorname{Pmax}(\mathrm{W})$ & $\mathrm{Vmax}(\mathrm{V})$ & $\operatorname{Imax}(\mathrm{A})$ & $\mathrm{FF}$ & $\mathrm{EFF}(\%)$ \\
\hline 276 & 0.02 & 0.084 & 0.000 & 0.011 & 0.025 & 0.218 & 0.00 \\
\hline 375 & 0.02 & 0.038 & 0.002 & 0.025 & 0.081 & 2.664 & 0.02 \\
\hline 437 & 5.33 & 0.048 & 0.117 & 5.330 & 0.022 & 0.458 & 0.93 \\
\hline 643 & 8.78 & 0.068 & 1.730 & 8.780 & 0.197 & 2.897 & 9.31 \\
\hline 743 & 8.43 & 0.077 & 1.585 & 8.430 & 0.188 & 2.442 & 7.38 \\
\hline 835 & 10.33 & 0.089 & 0.282 & 2.372 & 0.119 & 0.307 & 1.17 \\
\hline 912 & 11.50 & 0.146 & 1.679 & 11.500 & 0.146 & 1.000 & 6.37 \\
\hline 933 & 11.77 & 0.091 & 2.024 & 11.770 & 0.172 & 1.890 & 7.51 \\
\hline 1000 & 12.24 & 0.080 & 1.812 & 12.240 & 0.148 & 1.850 & 6.27 \\
\hline
\end{tabular}

$\mathrm{T}_{\bmod }=38.4^{\circ} \mathrm{C}, \mathrm{MPR}=0.19, \mathrm{P}_{\max }(\%)=18.12 \%$

The module performance for the four years of study was compared with Standard Test Condition (STC) specifications. The maximum power achieved at $1000 \mathrm{~W} / \mathrm{m}^{2}$ for the four years of study are $0.652 \mathrm{~W}, 2.186 \mathrm{~W}, 2.078 \mathrm{~W}$, and $1.812 \mathrm{~W}$ representing $6.52 \%, 21.86 \%$, $20.78 \%$ and $18.12 \%$ of the manufacturer's $10 \mathrm{~W}$ specification. Module efficiency at $1000 \mathrm{~W} / \mathrm{m}^{2}$ for the four years of study is $2.25 \%$, $7.56 \%, 7.19 \%$, and $6.27 \%$ respectively as against the manufacturers STC specification of $33 \%$. The Open voltage at $1000 \mathrm{~W} / \mathrm{m}^{2} \mathrm{recorded}$ $12.5 \mathrm{~V}, 11.6 \mathrm{~V}, 11.7 \mathrm{~V}$ and $12.2 \mathrm{~V}$ as against the manufacturers STC specification of $21.2 \mathrm{~V}$ for the four years of study while the short circuit currents are 0.08A, 0.09A, 0.09A and 0.08A as against the manufacturers STC specifications of 0.62A for the four years of study. Similarly, maximum voltage $\left(\mathrm{V}_{\max }\right)$ which according to manufacturers $\mathrm{STC}$ specification is $17.4 \mathrm{~V}$, recorded $12.5 \mathrm{~V}, 11.8 \mathrm{~V}, 11.74 \mathrm{~V}$ and $12.2 \mathrm{~V}$ at $1000 \mathrm{~W} / \mathrm{m}^{2}$ for the first, second, third and fourth year respectively, while the maximum current (Imax) recorded $0.05 \mathrm{~A}, 0.19 \mathrm{~A}$, $0.18 \mathrm{~A}$ and $0.15 \mathrm{~A}$ for the four years of study as against the manufacturers specification of $0.55 \mathrm{~A}$. Module performance ratios for the amorphous silicon module under investigation for the four years of study are $0.07,0.23,0.22$ and 0.19 respectively. It was equally observed that no year recorded module temperature of $25^{\circ} \mathrm{C}$ at $1000 \mathrm{~W} / \mathrm{m}^{2}$ solar irradiance as usually assumed for STC conditions as seen in Tables 5 for the four years of study. They all recorded module temperature $\left(\mathrm{T}_{\mathrm{mod}}\right)$ well beyond $25^{\circ} \mathrm{C}$ in the local environment. This four years study of amorphous module has also corroborated the works of [9]. This clearly shows that there is an enormous margin of deviation of the characterised values from the manufacturers STC specifications, and the STC data is a suspect as the above assertion was equally observed by [10]. Therefore designing with manufacturer's STC data will produce an unreliable and defective amorphous photovoltaic power system in Minna.

Annual yearly averages of performance variables and ambient parameters are shown in Table 9 for amorphous silicon module to ascertain the average annual Rate of Degradation (RoD).

Table 9:Annual Yearly Averages of Performance Variables and Ambient Parameters for the Amorphous Module

\begin{tabular}{|c|c|c|c|c|c|c|c|c|c|}
\hline T(Years) & $\mathrm{V}_{\mathrm{oc}}(\mathrm{V})$ & $\mathrm{I}_{\mathrm{sc}}(\mathrm{A})$ & $\mathrm{P}(\mathrm{W})$ & $\mathrm{P}_{\max }(\mathrm{W})$ & $\mathrm{T}_{\bmod }\left({ }^{0} \mathrm{C}\right)$ & $\mathrm{H}_{\mathrm{g}}\left(\mathrm{W} / \mathrm{m}^{2}\right)$ & $\mathrm{T}_{\mathrm{a}}\left({ }^{0} \mathrm{C}\right)$ & $\mathrm{WS}(\mathrm{m} / \mathrm{s})$ & $\mathrm{RH}(\%)$ \\
\hline YEAR1 (2015) & 3.21 & 0.038 & 0.173 & 0.244 & 35.4 & 507 & 25.4 & 1.65 & 48.3 \\
\hline YEAR2 (2016) & 2.55 & 0.031 & 0.221 & 0.277 & 35.5 & 520 & 31.4 & 1.57 & 49.7 \\
\hline YEAR3 (2017) & 1.76 & 0.014 & 0.206 & 0.237 & 36.4 & 502 & 32.3 & 1.34 & 47.1 \\
\hline YEAR4 (2018) & 1.84 & 0.001 & 0.141 & 0.185 & 36.1 & 485 & 32.7 & 1.03 & 53.1 \\
\hline
\end{tabular}

Table 10:Annual Average Rate of Degradation (Rod) of Performance Variables for the Amorphous Module

\begin{tabular}{|c|c|c|c|c|}
\hline $\mathrm{T}$ (Years) & $\mathrm{V}_{\mathrm{oc}}(\mathrm{V})$ & $\mathrm{I}_{\mathrm{sc}}(\mathrm{A})$ & $\mathrm{P}(\mathrm{W})$ & $\operatorname{Pmax}(\mathrm{W})$ \\
\hline 2015 to 2016 & 0.66 & 0.007 & 0.048 & 0.033 \\
\hline 2016 to 2017 & 0.79 & 0.017 & 0.015 & 0.040 \\
\hline 2017 to 2018 & 0.08 & 0.013 & 0.065 & 0.052 \\
\hline
\end{tabular}

From Table 10, it was observed that $\mathrm{V}_{\mathrm{oc}}$ and $\mathrm{I}_{\mathrm{sc}}$ has a yearly decrease of $0.66 \mathrm{~V}$ and $0.007 \mathrm{~A}$ from year 2015 to 2016 , $0.79 \mathrm{~V}$ and $0.017 \mathrm{~A}$ from 2016 to 2017, 0.013A for Isc from 2017 to 2018 and a slight increase of 0.08V from 2017 to 2018 for Voc. Furthermore, no decrease was noticed for $\mathrm{P}$ and $\mathrm{P}_{\max }$ in the first year, but rather a slight increase of $0.048 \mathrm{~W}$ and $0.033 \mathrm{~W}$ from year 2015 to 2016 was seen. It was discovered that $\mathrm{P}$ and $\mathrm{P}_{\max }$ decreased by $0.015 \mathrm{~W}$ and $0.04 \mathrm{~W}$ from 2016 to $2017,0.065 \mathrm{~W}$ and $0.052 \mathrm{~W}$ from 2017 to 2018 suggesting that $\mathrm{P}$ and $\mathrm{P}_{\max }$ began degrading steadily after year 2016. Annual average Rate of Degradation (RoD) for the four years was computed for only the performance variables which reveals that Voc, $\mathrm{I}_{\mathrm{sc}}, \mathrm{P}$ and $\mathrm{P}_{\max }$ has an annual average RoD of $0.73 \mathrm{~V}, 0.010 \mathrm{~A}, 0.040 \mathrm{~W}$ and $0.050 \mathrm{~W}$ respectively for the four years of study as shown in Table 4.10 above. Annual yearly average plots of the performance variables are shown in Figures 29 and 30. 


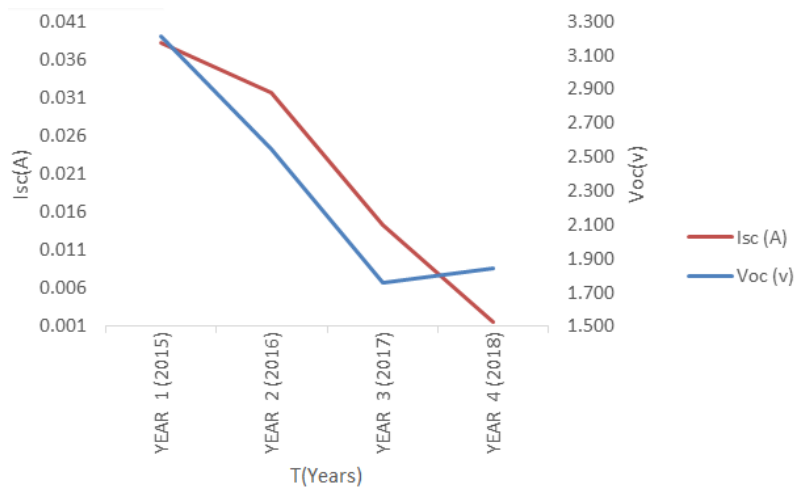

Fig. 29:Variation of Short Circuit Current and Open Circuit Voltage as A Function of Years.

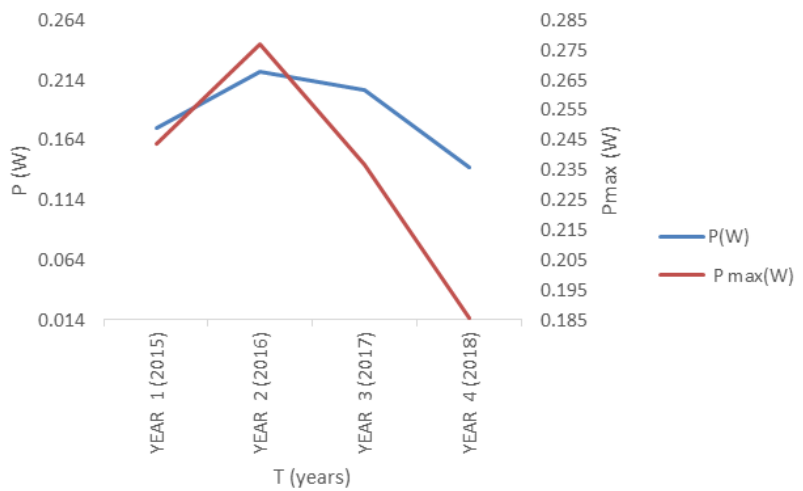

Fig. 30:Variation of Power Output and Maximum Power as A Function of Years

Figure 29 and 30 shows the degradation rate for the performance variables being investigated. It was discovered that short- circuit current (Isc) and open-circuit voltage $\left(\mathrm{V}_{\mathrm{oc}}\right)$ decreased steadily from year 2015 to 2018 . However, it was observed that the degradation trend was distorted in 2018 where $V_{o c}$ was high. This is due to the fact that according to earlier work of [9], $V_{o c}$ are known to be affected negatively by high module temperature which accounted for the sudden increase of $\mathrm{V}_{\text {ocin }}$ year 2018 when a decrease in module temperature was noticed as shown in Table 9. The other parameters worthy of note are power $(\mathrm{P})$ and maximum power $\left(\mathrm{P}_{\max }\right)$. From the plots of Figure 30 , it was observed that there was an increase from 2015 to 2016 before it starts decreasing. The reason for the increase in the first year is not farfetched, according to [9] and other researchers in this field, increase in solar irradiance $(\mathrm{Hg})$ and module temperature ( $\left.\mathrm{T}_{\mathrm{mod}}\right)$ increases $\mathrm{P}_{\max }$, and $\mathrm{P}$. Therefore, increase in $\mathrm{Hg}$ and $\mathrm{T}_{\bmod }$ as seen in Table 9 has accounted for the increase noticed for the $\mathrm{P}$ and $\mathrm{P}_{\max }$ in the first year.

\subsection{Statistical analysis and models}

The data collected for this research work was experimental data over four year period from 2015 to 2018 . Minitab version 17 statistical software and Microsoft Excel was used to analyse the data. Both descriptive and inferential statistics was used in analysing the data, Regression model of three variables which include $\operatorname{Voc}(\mathrm{V})$, Isc(A) and $\mathrm{P}(\mathrm{W})$ was regressed over the four years. A 20 years forecast from the model was derived to determine whether there is downward or upward trend of the experimental data.

A multiple regression model was developed with three independent variables which include Voc (V), Isc (A) and P (W) and one dependent variable Years. The Regression equation model for the research work is

$\mathrm{YEAR}=3.36-0.237 \mathrm{~V}_{\mathrm{oc}}(\mathrm{v})-71.5 \mathrm{I}_{\mathrm{sc}}(\mathrm{A})+8.07 \mathrm{P}(\mathrm{W})$

From equation 4.1, for every unit increase in Voc (V) there is 0.237 decrease in the years value keeping Isc (A) and Power (W) constant. For every unit increase in Isc (A) there is 71.5 decrease in the Year's value keeping Voc (V) and Power (W) constant which shows very fast downward trend of the values than the Voc $(\mathrm{V})$.Also for every unit increase in P (W), there is 8.07 increase in the Year's value keeping Voc (V) and Isc (A) constant. The percentage decrease of Isc (A) contributed to the fast decrease in the values as the year's increases.

\subsection{Forecasting}

A 20 years forecasting of the performance variables used for this study was done using the model developed and tabulated with the predicted values as in Table 14 .

Table 14:A Twenty (20) Years Forecasting Table

\begin{tabular}{|c|c|c|c|c|c|c|c|c|c|c|}
\hline & & & & & & & & & & \\
\hline Predicted Values & 5350 & 11725 & 18007 & 24450 & 30826 & $\frac{2024}{37100}$ & $\frac{2025}{12550}$ & 2020 & $\frac{2021}{56200}$ & $\frac{2020}{62650}$ \\
\hline Years & 2029 & 2030 & 2031 & 2032 & 2033 & 2034 & 2035 & 2036 & 2037 & 2038 \\
\hline Predicted Values & -690.26 & -753.92 & -817.59 & -881.26 & -944.93 & -1008.59 & -1072.26 & -1135.93 & -1199.59 & -1263.26 \\
\hline
\end{tabular}




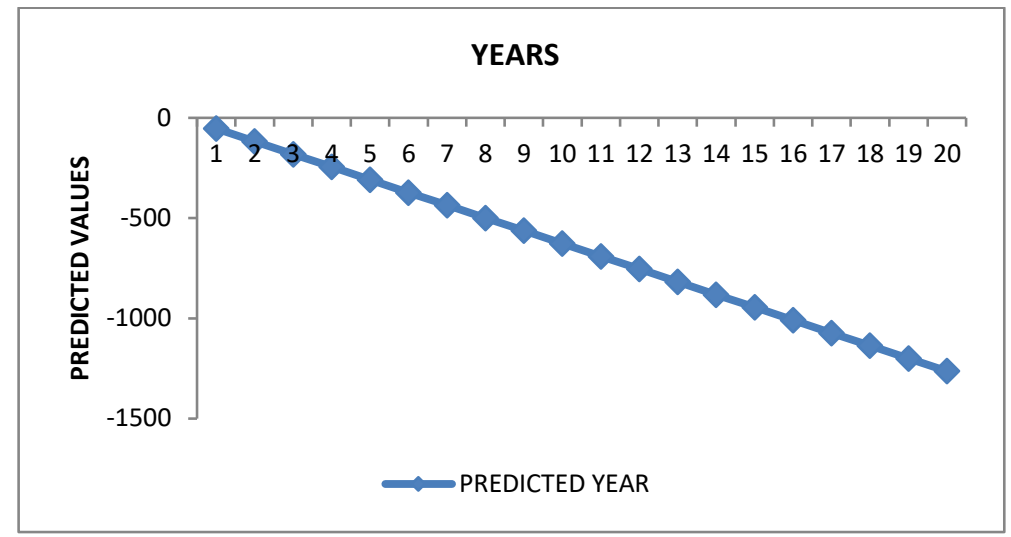

Fig. 31:Shows the Line Graph of the Downward Trend of the Predicted Values Over A 20 Years Period.

Keys:

- $\quad$ Year $1=2019$
- $\quad$ Year $2=2020$
- $\quad$ Year $3=2021$
- $\quad$ Year $4=2022$
- $\quad$ Year $5=2023$
- $\quad$ Year $6=2024$
- $\quad$ Year $7=2025$
- $\quad$ Year $9=2026$
- $\quad$ Year $10=2027$

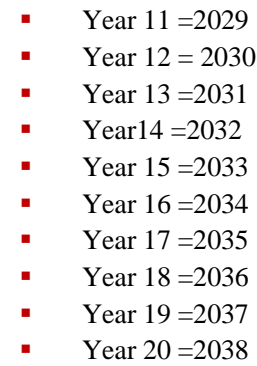

Fig. 32:Line Graph of the Predicted Value for the Performance Variables.

\section{Conclusion}

The outdoor characterisation and performance evaluation of amorphous silicon photovoltaic module in Minna local environment for the four years study period reveals that the actual values of performance variables of the module differ greatly from the manufacturer's specifications. The maximum power achieved at $1000 \mathrm{~W} / \mathrm{m}^{2}$ for the four years of study are $0.652 \mathrm{~W}, 2.186 \mathrm{~W}, 2.078 \mathrm{~W}$, and $1.812 \mathrm{~W}$ representing $6.52 \%, 21.86 \%, 20.78 \%$ and $18.12 \%$ of the manufacturer's $10 \mathrm{~W}$ specification. Module efficiency at $1000 \mathrm{~W} / \mathrm{m}^{2}$ for the four years of study is $2.25 \%, 7.56 \%, 7.19 \%$, and $6.27 \%$ respectively as against the manufacturers STC specification of $33 \%$. Similarly, it was equally observed that no year recorded module temperature of $25^{\circ} \mathrm{C}$ at $1000 \mathrm{~W} / \mathrm{m}^{2}$ irradiance as used in STC specifications by the manufacturer. Instead, the four years study recorded module temperature $\left(\mathrm{T}_{\bmod }\right)$ well beyond $25^{\circ} \mathrm{C}$ in the local environment. This clearly shows that there is an enormous margin of deviation of the characterised values from the manufacturers STC specifications, and the STC data is a suspect as the above assertion was equally observed by [10]. Therefore designing with manufacturer's STC data will produce an unreliable and defective amorphous photovoltaic power system.

The yearly determination of Rate of Degradation (RoD) of amorphous photovoltaic modules in Minna local environment reveals that all the performance variables of the module degraded significantly from year to year for the four years of study. It reveals that $\mathrm{V}_{\mathrm{oc}}, \mathrm{I}_{\mathrm{sc}}, \mathrm{P}$ and $\mathrm{P}_{\max }$ has an annual average RoD of $0.73 \mathrm{~V}, 0.010 \mathrm{~A}, 0.040 \mathrm{~W}$ and $0.050 \mathrm{~W}$ respectively for the four years of study. Similarly, It was observed that $\mathrm{V}_{\mathrm{oc}}$ and $\mathrm{I}_{\mathrm{sc}}$ has a yearly decrease of $0.66 \mathrm{~V}$ and $0.007 \mathrm{~A}$ from year 2015 to 2016, 0.79V and 0.017A from 2016 to 2017, 0.013A for $\mathrm{I}_{\mathrm{sc}}$ from 2017 to 2018 and a slight increase of $0.08 \mathrm{~V}$ from 2017 to 2018 for $\mathrm{V}_{\text {oc. }}$. Furthermore, no decrease was noticed for $\mathrm{P}_{\text {and }} \mathrm{P}_{\mathrm{max}}$ in the first year, but rather a slight increase of $0.048 \mathrm{~W}$ and $0.033 \mathrm{~W}$ from year 2015 to 2016 was seen. It was discovered that $\mathrm{P}$ and $\mathrm{P}_{\max }$ decreased by $0.015 \mathrm{~W}$ and $0.04 \mathrm{~W}$ from 2016 to $2017,0.065 \mathrm{~W}$ and $0.052 \mathrm{~W}$ from 2017 to 2018 suggesting that $\mathrm{P}$ and $\mathrm{P}_{\max }$ began degrading steadily after year 2016. Module temperature was therefore observed to have significant influence on the general degradation of the module especially $\mathrm{V}_{\text {oc }}$ because it has no linear relationship with temperature and solar irradiance hence the increase when temperature decreased in 2018. In addition to the temperature effects on the degradation of the module is solar irradiance which is seen to affect $\mathrm{P}$ and $P_{\max }$, hence the increase when temperature and solar irradiance increased in the first year of study.

\section{Recommendations}

Although yearly performance and Rate of Degradation (RoD) has been extensively carried out under Minna prevailing meteorological parameters, however, there are still areas where work needs to be done.

i). Various studies suggest that amorphous module degrade over time after long time of outdoor exposure, only four years study was considered in this work. It is, therefore, recommended that longer years of outdoor exposure be carried out in the Minna local environment.

ii). It is also recommended that outdoor, yearly degradation studies should be carried out on all commercially available PV modules in every location of developing countries where this is lacking. Results will furnish policy makers, designers, PV power system installers the vital information on the degradation rate and lifespan of all commercially available PV modules for effective and reliable PV power system. 


\section{Acknowledgement}

I wish to acknowledge and thank Ezenwora Joel Aghaegbunam for allowing me use his solar laboratory located at the Federal University of Technology, Minna for this research work.

\section{References}

[1] Dunlop E. \& Halton D. (2006). The performance of crystalline silicon photovoltaic solar modules after 22 years of exposure. Progress in photovoltaic Research applications, 7:16-23.

[2] René, J. (2005). Introduction to polymer solar cells. Eindhoven University of Technology, Netherlands. 3 Y280

[3] Azhar G. \& Abdul M. (2012).The performance of three different solar panels for solar electricity applying solar tracking device under the Malaysian climate condition. Energy and environment research, 2: 235-243

[4] Duke R., Graham S., Mark H., Arne J., Daniel M., Osawa B., Simone P. \& Erika W. (1999). Field performance evaluation of amorphous silicon (a-si) photovoltaic systems in kenya: methods and measurements in support of a sustainable commercial solar energy industry. A Project of Energy Alternatives Africa (EAA) and Renewable Appropriate Energy Laboratory (RAEL) and Energy and Resources Group (ERG), University of California, Berkeley

[5] Rakovect, J. \& Klemen, Z. (2011).Orientation and tilt dependence of a fixed PV array energy yield based on measurements of solar energy and ground albedo- A Case Study of Slovenia. Progress Report on Photovoltaics: Research and Applications, 13 : $42-51$.

[6] Manuel V. \& Ignacio R. (2008).Photovoltaic module reliability model based on field degradation studies. Progress report on photovoltaics:research and applications, 10: 825-1002

[7] S.J. Strong \& W.G. Scheller, (1991). The Photovoltiac Room. 2nd ed. Sustainability Press, Massachusetts.

[8] P.E. Ugwuoke, F.I. Ezema\& C.E. Okeke (2005). Performance Response of Monocrystalline PV Modules to Some Meteorological Parameters at Nsukka, Nigerian Journal of Space Research, 3 (2), 63-69.

[9] Ezenwora, J.A; (2016).Development of a prototype photovoltaic power system based on characterization and performance evaluation of photovoltaic modules in Minna, Nigeria.PhD Thesis, Department Of Physics, Federal University of Technology, Minna .pp 45-140

[10] Carr A. (2005). A detailed performance comparison of pv modules of different technologies and the implications for the pv system design methods. Phd thesis; murdock university. Western Australia. 